UNIVERSIDADE DE SÃO PAULO

FFCLRP - DEPARTAMENTO DE PSICOLOGIA

PROGRAMA DE PÓS-GRADUAÇÃO EM PSICOLOGIA

Sintomas de estresse e percepção de estressores escolares no início do Ensino Fundamental

Erica Taciana dos Santos Crepaldi

Dissertação apresentada à Faculdade de Filosofia, Ciências e Letras de Ribeirão Preto da USP, como parte das exigências para a obtenção do título de Mestre em Ciências, Área: Psicologia.

RIBEIRÃO PRETO - SP

2016 


\section{Sintomas de estresse e percepção de estressores escolares no início do Ensino Fundamental}

Dissertação apresentada à Faculdade de Filosofia, Ciências e Letras de Ribeirão Preto da USP, como parte das exigências para a obtenção do título de Mestre em Ciências, Área de concentração: Psicologia ${ }^{1}$

Orientadora: Prof ${ }^{\mathrm{a}} \operatorname{Dr}^{\mathrm{a}}$ Edna Maria Marturano

"Versão corrigida"

RIBEIRÃO PRETO - SP

2016

\footnotetext{
${ }^{1} \mathrm{O}$ projeto mais amplo que deu origem a esta pesquisa foi desenvolvido pela $\mathrm{Dr}^{\mathrm{a}}$ Marta Regina Gonçalves Correia Zanini, que faz parte da equipe de pesquisa.
} 
Autorizo a reprodução e divulgação total ou parcial deste trabalho, por qualquer meio convencional ou eletrônico, para fins de estudo e pesquisa, desde que citada a fonte.

Crepaldi, Erica Taciana dos Santos

Sintomas de estresse e percepção de estressores escolares no início do Ensino Fundamental. Ribeirão Preto, 2016.

75 p.; $30 \mathrm{~cm}$

Dissertação de Mestrado, apresentada à Faculdade de Filosofia, Ciências e Letras de Ribeirão Preto - USP. Área de concentração: Psicologia.

Orientador: Marturano, Edna Maria.

1. Estresse infantil. 2. Transição escolar. 3. Ensino Fundamental. 4.Habilidades Sociais. 
Nome: Crepaldi, Erica Taciana dos Santos

Título: Sintomas de estresse e percepção de estressores escolares no início do Ensino Fundamental.

Dissertação apresentada ao Programa de Pós-Graduação em Ciências, da FFCLRP, da Universidade de São Paulo, para obtenção do título de Mestre em Ciências, área de concentração: Psicologia.

Aprovado em: $/ 2016$

Banca Examinadora

Prof. Dr.

Instituição: Assinatura:

Prof. Dr.

Instituição: Assinatura:

Prof. Dr.

Instituição: Assinatura: 
Dedico este trabalho ao meu esposo Gabriel, com amor e gratidão por todo apoio e compreensão ao longo da elaboração deste trabalho, e à minha filha amada Heloísa... 


\section{AGRADECIMENTOS}

A Deus, por ser tão providente em minha vida, capacitando-me e possibilitando a realização deste trabalho, colocando em meu caminho pessoas tão especiais como essas que tenho gratidão por compartilhar este momento.

Aos meus pais, Salete e Geraldo dos Santos, por me ensinarem o valor do estudo e serem os primeiros incentivadores da minha profissão. Obrigada por respeitarem minhas escolhas e por compreenderem a minha ausência nos momentos em que este trabalho tornou-se prioridade.

À professora Edna Maria Marturano, que aceitou me orientar desde o primeiro encontro e assumiu o desafio de me iniciar no mundo da pesquisa. Obrigada por me orientar com tanta dedicação, sabedoria e entusiasmo. É um privilégio poder aprender contigo um pouco do seu vasto conhecimento.

À Marta Correia Zanini, que esteve comigo durante todo o processo, antes mesmo da minha aprovação na seleção do mestrado. Obrigada por compartilhar não só o banco de dados da sua pesquisa, mas todo seu conhecimento e experiência; por acolher não só as minhas dúvidas, mas minhas angústias.

Às professoras Patrícia Leila dos Santos e Marlene Trivellato Ferreira que aceitaram prontamente participar da minha banca de qualificação e pelas contribuições primorosas que deram a este trabalho, enriquecendo-o.

À Priscila R. Manzoli, por ter me apresentado à professora Edna M. Marturano e ter me incentivado a dar os primeiros passos neste projeto. Pri, sou muito grata pelo seu apoio e torcida!

Ao meu irmão Thiago dos Santos e cunhada Jéssica F. dos Santos, pela torcida, companheirismo e apoio, não só no mestrado, mas na vida, podendo recorrê-los sempre que precisei.

A todos meus familiares, tios, primos, sogros, cunhados e avós, pela torcida, apoio e compreensão nos momentos em que me ausentei. Agradeço pelas orações, mensagens e telefonemas de apoio, desde o processo seletivo para a entrada no mestrado. Vocês estão sempre presentes, mesmo a quilômetros de distância.

Aos meus primos e compadres Karina e Antônio Albuquerque Junior, pela alegria de me confiar o batizado de vosso filho Bruno e serem compreensivos ao ajustarem datas tão importantes como o batizado e as festas de aniversário dele aos meus compromissos com este trabalho. Bruno, meu amor, a madrinha quer estar cada vez mais perto de você e mais ajustada aos seus compromissos!

À minha prima Mariana Galuch, com quem pude compartilhar toda minha trajetória e contar com seu apoio e torcida. Mari, embora suas conquistas tenham levado você ainda mais longe 
de mim, apenas geograficamente, fico muito feliz por ver sua coragem, crescimento pessoal e alegria como professora universitária. Você é merecedora!

À minha amiga Flávia Sgarbosa Gomes, que desde a graduação se faz tão presente em minha vida, de forma carinhosa, cuidadosa e prestativa. Obrigada por toda ajuda e atenção. Flávia, você tem morada fixa no meu coração!

À Bárbara M. Costa, amiga da graduação que pude conhecer melhor anos depois de formada. Bárbara, embora te conhecesse há mais tempo, acredito que nossa aproximação seu deu no momento certo de nossas vidas. Agradeço a sua escuta acolhedora, os conselhos terapêuticos, as piadas e o incentivo e apoio em todos os meus projetos.

Aos meus amigos de trabalho da clínica Andreza R. Gomes, Hugo Gomes e Josiane Campos com quem pude compartilhar as minhas angústias durante este processo e aprender com as suas vivências de pesquisadores. Vocês são mais do que colegas de trabalho para mim, são amigos e inspiração para a minha profissão. Agradeço em especial a Josiane, que destinou tempo precioso da sua rotina para me ensinar sobre pesquisa e, principalmente, a olhar os meus resultados, proporcionando momentos de muito aprendizado, enriquecendo este trabalho.

Às minhas amigas Juliana Caseiro e Ana Cristina Rani, pelo acolhimento e apoio nos momentos mais difíceis que enfrentei em Ribeirão Preto. Vocês foram muito importantes para que eu levasse adiante os meus projetos.

À Luana Vanni por ter sido tão prestativa, paciente e confidente durante este processo. Contar com sua eficiência na organização do meu trabalho na clínica foi de extrema importância para a realização do meu mestrado.

À Fabiana Guerrelhas, minha psicoterapeuta, supervisora clínica e colega de profissão, que acompanhou de perto toda a minha curta e turbulenta trajetória em Ribeirão Preto. É muito bom poder compartilhar esta história contigo e contar com seu apoio.

Às amigas que conheci no mestrado e que pretendo levar para a vida toda Gabriela Guarnieri, Marina Cilino e Maria Eduarda Pedro. Gabi, não esqueço do seu acolhimento e apoio quando te conheci minutos antes de iniciar a prova de seleção; foi muito bom te reencontrar depois nas disciplinas e comemorar a aprovação contigo. Maria Eduarda, obrigada pela parceria com as atividades das disciplinas e pela ajuda nas questões práticas que uma ribeirão-pretana solícita e de coração generoso é capaz. Marina, foi terapêutico e prazeroso compartilhar contigo as angústias e alegrias de ser mestranda e também de ser gestante-mestranda; espero continuar compartilhando tantas emoções como estas com você. Vocês três tornaram esta jornada mais leve e prazerosa.

Às minhas eternas vizinhas Débora Savassi e Erika Casale, pela amizade gratuita, pelos socorros prestados e por compreenderem a minha indisponibilidade de tempo para nossas conversas.

À amiga Roberta Pereira que se fez presente neste processo com apoio e incentivo. 
Ao meu esposo Gabriel Crepaldi, principal incentivador e facilitador deste processo. Impossível olhar para esta dissertação e não me lembrar de ti. É difícil mensurar sua vasta participação neste processo, pois você esteve presente em todos os momentos. Leu não só cada frase desta dissertação (algumas partes mais de uma vez) como também alguns trabalhos de disciplinas, sempre de forma criteriosa. Meu amor, seu conhecimento e olhar crítico de pesquisador na área de Reprodução de Bovinos foi de extrema relevância para o meu trabalho. Contudo, seu amor, apoio e compreensão foram imprescindíveis para que eu realizasse o meu mestrado. É com muita alegria que termino este processo junto com você, com nosso casamento mais fortalecido, comemorando não só a conclusão desta pesquisa, mas também a chegada da nossa filha Heloísa. Gabriel, desejo a nós muitos projetos e desafios repletos de muitos atos de amor e companheirismo. 


\section{RESUMO}

Crepaldi, E. T. S. (2016). Sintomas de estresse e percepção de estressores escolares no início do ensino fundamental. Dissertação de Mestrado, Faculdade de Filosofia, Ciências e Letras de Ribeirão Preto, Universidade de São Paulo, Ribeirão Preto, SP.

O ingresso no Ensino Fundamental - EF tem sido visto como um momento de transição devido às novas demandas que apresenta para a criança. Neste contexto, parece haver um aumento da vulnerabilidade das crianças ao estresse, principalmente daquelas com maior dificuldade de adaptação a estas demandas. Esse estudo teve como objetivo amplo investigar o estresse da transição no contexto do EF de nove anos, partindo de uma visão desenvolvimentista aliada a uma perspectiva de exposição a estressores cotidianos. Especificamente, o estudo investigou a relação entre competências e sintomas de estresse no $1^{\circ}$ ano do EF, o curso desenvolvimental dos sintomas e das percepções de estresse nos dois anos inicias do EF, suas associações com as tarefas adaptativas da transição e a influência da escola nos indicadores de estresse. Finalmente, exploraram-se modelos explicativos para indicadores de estresse apresentados no $2^{\circ}$ ano. Seguindo metodologia prospectiva, avaliaram-se indicadores de ajustamento e competências relacionadas ao desempenho acadêmico, social e comportamental das crianças no $1^{\circ}$ ano, estresse nos dois primeiros anos e características da escola (localização e IDEB). Participaram da pesquisa 157 alunos do $1^{\circ}$ ano do EF, sendo 85 meninos e 72 meninas, com idade média de 6 anos e 10 meses no início da pesquisa. Todos tinham experiência de dois anos na Educação Infantil e estavam matriculados em escolas municipais de diferentes regiões de uma cidade do interior de São Paulo. Também participaram do estudo, como informantes, seus respectivos professores do $1^{\circ}$ ano, num total de 25 . As crianças responderam à Escala de Stress Infantil, ao Inventário de Estressores Escolares e a uma avaliação objetiva de desempenho acadêmico (Provinha Brasil). Os professores avaliaram as habilidades sociais, os problemas de comportamento externalizantes e internalizantes e a competência acadêmica dos seus alunos por meio do Social Skills Rating System - Professores. A análise dos dados compreendeu estatísticas descritivas, comparações, correlações e regressões. Nos resultados, $57 \%$ dos alunos no $1^{\circ}$ ano e $72 \%$ no $2^{\circ}$ ano relataram sintomas de estresse pelo menos na fase de alerta. Crianças com estresse no $1^{\circ}$ ano apresentaram menores índices de ajustamento e competência e perceberam suas escolas como mais estressantes em relação ao seu papel de estudante e nas relações interpessoais. Correlações moderadas entre medidas de indicadores de estresse tomadas no $1^{\circ}$ e no $2^{\circ}$ ano sugerem estabilidade. A presença de sintomas de estresse aumentou do $1^{\circ}$ para o $2^{\circ}$ ano, enquanto a percepção de estressores escolares não variou. Crianças com maiores médias de estresse são provenientes de escolas situadas em regiões periféricas e com classificação mais baixa no IDEB. As análises de predição evidenciaram a habilidade social de responsabilidade e cooperação avaliada no $1^{\circ}$ ano como importante fator de proteção contra sintomas de estresse no $2^{\circ}$ ano, ao passo que a percepção da criança de tensões nas relações interpessoais no $1^{\circ}$ ano foi o principal fator de risco para futura sintomatologia de estresse. Nesse sentido, intervenções com ênfase na promoção de habilidades sociais das crianças podem ser profícuas na prevenção do estresse.

Palavras-chave: Estresse infantil. Transição escolar. Ensino Fundamental. Habilidades sociais. 


\begin{abstract}
Crepaldi, E. T. S. (2016). Stress symptoms and school stress perceptions in the beginning of elementary school. Dissertação de Mestrado, Faculdade de Filosofia, Ciências e Letras de Ribeirão Preto, Universidade de São Paulo, Ribeirão Preto, SP.
\end{abstract}

The entrance to the elementary school - ES has been considered as a transition time due to the new demands it presents for the child. In this context, some children may become more vulnerable to stress, especially those with greater difficulty in adapting to these demands. This study investigates the stress of transition to ES (nine years long), from a developmental perspective combined with the theoretical approach of exposure to daily hassles. Specifically, the study investigated (a) the relationship between competences and symptoms of stress in the 1st year of the ES; (b) the developmental course of symptoms and stress perceptions in the two initial years of the ES; (c) their associations with adaptive transition tasks; (d) the school influence on stress indicators. Explanatory models for stress indicators presented in $2^{\text {nd }}$ year were also explored up. Following a prospective design, competence and adjustment indicators related to academic performance, social skills, behavior, and stress were evaluated in the $1^{\text {st }}$ year, as well as school characteristics (location and IDEB). Stress measures were repeated in the $2^{\text {nd }}$ year. The participants were 157 ES students, 85 boys and 72 girls, with an average age of 6 years and 10 months at baseline in $1^{\text {st }}$ year. They had two years experience in kindergarten and were enrolled in public schools in different regions of a city of São Paulo State. Their teachers of the $1^{\text {st }}$ year, a total of 25 , also participated in the study, as informants. The children answered the Child Stress Scale, the Inventory of School Stressors and an objective evaluation of academic performance (Provinha Brazil). Teachers rated social skills, externalizing and internalizing behavior problems and academic competence of their students through the Social Skills Rating System - Teachers. Data analysis comprised descriptive statistics, comparisons, correlations and regressions. In the results, $57 \%$ of students in the $1^{\text {st }}$ year and $72 \%$ in the $2^{\text {nd }}$ reported stress symptoms at least in the alert phase. Children with stress symptoms at $1^{\text {st }}$ year had lower levels of adjustment and competence. They also perceived their schools as more stressful concerning both academic demands and interpersonal relationships. Moderate correlations between stress indicators measures in the $1^{\text {st }}$ and $2^{\text {nd }}$ year suggest stability. The presence of stress symptoms increased from the $1^{\text {st }}$ to the $2^{\text {nd }}$ year, while the perception of school stressors did not change. Children with higher average stress come from schools in remote urban areas and lower IDEB index. The prediction analysis showed the social skill of responsibility and cooperation assessed at $1^{\text {st }}$ year as an important protection factor against stress symptoms in the $2^{\text {nd }}$ year, while the child's perception of tensions in interpersonal relationships in the $1^{\text {st }}$ year was the main risk factor for future symptoms of stress. In this sense, interventions emphasizing the promotion of social skills of children can be fruitful in preventing stress.

Keywords: Childhood stress. School transition. Elementary school. Social skills. 


\section{LISTA DE TABELAS}

Tabela 1 - Estatísticas descritivas das variáveis de competência e ajustamento da criança avaliadas no $1^{\circ}$ ano

Tabela 2 - Comparação entre crianças avaliadas com estresse e sem estresse no $1^{\circ}$ ano nas outras variáveis da criança avaliadas no mesmo ano.

Tabela 3 - Correlações entre as variáveis de competência e ajustamento da criança avaliadas no $1^{\circ}$ ano e as variáveis relacionadas ao estresse no $2^{\circ}$ ano.

Tabela 4 - Comparação das médias de sintomas de estresse e de percepção de estressores escolares obtidas pelos alunos no $1^{\circ}$ e no $2^{\circ}$ ano do EF..

Tabela 5 - Correlações entre sintomas de estresse e percepção de estressores escolares avaliados no $1^{\circ}$ e no $2^{\circ}$ ano.

Tabela 6 - Correlações entre as características das escolas (localização e IDEB 2009) e os sintomas de estresse e a percepção de estressores escolares nos dois fatores avaliados no $2^{\circ}$ ano

Tabela 7 - Comparação das médias de sintomas de estresse e percepção de estressores escolares de crianças de acordo com a localização das suas escolas, no $2^{\mathrm{a}}$ ano.

Tabela 8 - Distribuição do número de crianças sem estresse e com estresse no $2^{\circ}$ ano de acordo com a localização das escolas.

Tabela 9 - Comparação entre escolas que obtiveram média abaixo de 6 no IDEB 2009 e escolas que obtiveram média igual ou acima de 6 segundo os sintomas de estresse e a percepção de estressores escolares das crianças no $2^{\circ}$ ano

Tabela 10 - Análise de regressão linear múltipla para a predição de sintomas de estresse no $2^{\circ}$ ano.

Tabela 11 - Análise de regressão linear múltipla para a predição de percepção de estressores escolares - F1: Tensões relacionadas ao papel de estudante, no $2^{\circ}$ ano

Tabela 12 - Análise de regressão linear múltipla para a predição de percepção de estressores escolares - F2: Tensões cotidianas nas relações interpessoais, no $2^{\circ}$ ano. 


\section{SUMÁRIO}

1. INTRODUÇÃ

1.1. A criança no primeiro ciclo do EF em uma visão de desenvolvimento..... 13

1.2. A criança no primeiro ciclo do EF em uma perspectiva de exposição a estressores cotidianos...................................................................... 17

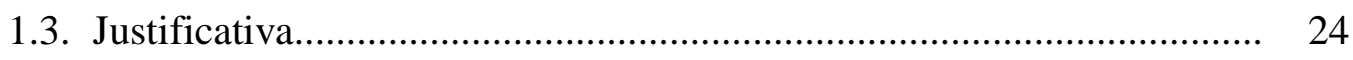

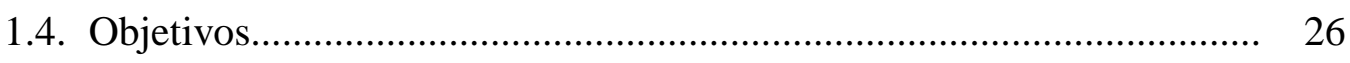

1.4.1. Objetivos gerais........................................................... 26

1.4.2. Objetivos específicos....................................................... 27

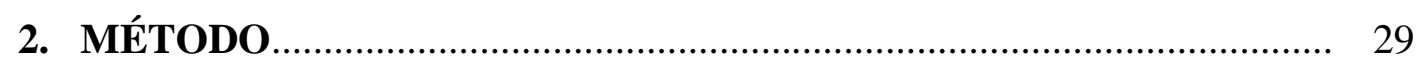

2.1. Considerações éticas................................................................... 29

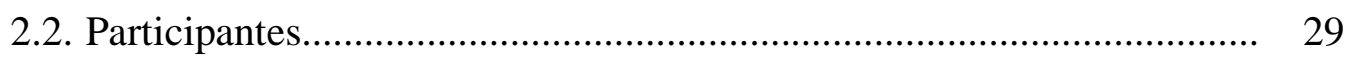

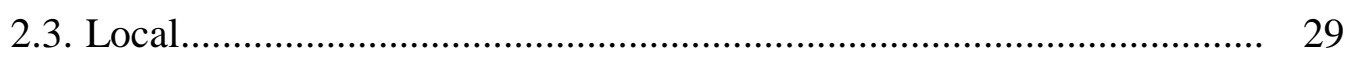

2.4. Materiais, instrumentos e fonte de dados........................................... 29

2.5. Procedimento de coleta de dados....................................................... 32

2.6. Procedimento de análise dos dados........................................................ 33

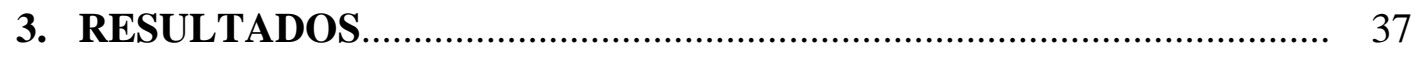

3.1. Percentual de alunos com sintomas de estresse................................. 37

3.2. Estatísticas descritivas das variáveis da criança e comparação de crianças com e sem estresse no $1^{\circ}$ ano do EF

3.3. Associações entre indicadores de estresse avaliados no $2^{\circ}$ ano do EF e as variáveis de competência e ajustamento da criança avaliadas no $1^{\circ}$ ano.

3.4. Comparação e associação dos níveis de estresse e de percepção de estressores escolares nos dois fatores (relacionado ao papel de estudante e às relações interpessoais) dos alunos no $1^{\circ}$ e no $2^{\circ}$ ano do EF.

3.5. Caracterização das escolas e associações entre indicadores de estresse da criança avaliados no $2^{\circ}$ ano e as características da escola (pontuação no IDEB e localização). 
3.6. Predição de manifestações de estresse (sintomas de estresse e percepção de estressores escolares relacionado ao papel de estudante e às relações interpessoais) avaliados no $2^{\circ}$ ano a partir de variáveis da criança e da escola avaliadas no $1^{\circ}$ ano.

4. DISCUSSÃ

5. CONCLUSÃO

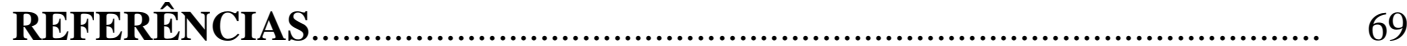

ANEXO 


\section{INTRODUÇÃO}

O ingresso no ensino fundamental (EF) tem sido visto como um momento de transição, pela diversidade de demandas novas que apresenta para a criança. Também tem sido assinalada a sua importância no curso do desenvolvimento posterior. Como assinalam Marturano, Trivellato-Ferreira e Gardinal (2009), experiências vividas no início do EF podem ter influência na trajetória futura da criança na escola. Isto posto, o presente estudo, ao focalizar crianças nos anos iniciais do EF, leva em consideração que essa fase constitui, ao mesmo tempo, um período influente na trajetória do aluno e um momento de demandas aumentadas. Para atender a essa dupla característica, adota-se uma visão de desenvolvimento aliada a uma perspectiva de exposição a estressores cotidianos.

\subsection{A criança no primeiro ciclo do EF em uma visão de desenvolvimento}

Dentro da perspectiva da ciência do desenvolvimento humano, o ciclo da vida se processa em uma sequência de estágios e transições. Como assinalam Aspesi, Dessen e Chagas (2005), estágios são caracterizados por padrões comportamentais e habilidades típicos de uma determinada idade ou fase do ciclo de vida, que estão relacionados ao processo reprodutivo da sociedade. Em cada estágio há a exigência de desempenho de tarefas específicas, codeterminadas pela biologia e pela cultura, conhecidas como tarefas de desenvolvimento (Masten \& Coastworth, 1998).

Ainda que com diferentes nomenclaturas e pequenas variações nas idades limítrofes, os tratados sobre desenvolvimento em geral reconhecem sete estágios no ciclo da vida humana, a partir do nascimento: infância (até 2 anos), idade pré-escolar (de 2 a 6 anos), idade escolar (de 6 a 10 anos), adolescência (10-20 anos), fase do jovem adulto (20-40 anos), maturidade (40-60 anos) e velhice (a partir de 60 anos) (Bee, 1997; Belsky, 2010). A passagem de um estágio para outro é denominada transição de vida e se define pela emergência de novas tarefas de desenvolvimento. As transições, pelos desafios que apresentam, são oportunidades para a expansão das habilidades individuais que a pessoa em desenvolvimento precisará mobilizar para lidar com as exigências de cada novo estágio (Aspesi et al., 2005).

Desse modo, o desenvolvimento humano se processa por meio das constantes adaptações do indivíduo ao ambiente, numa busca pelo restabelecimento do equilíbrio perdido a partir de circunstâncias novas ou adversas, geradoras de tensões. Por isso, a compreensão do 
desenvolvimento humano está atrelada à investigação dos processos adaptativos do indivíduo ao meio (Aspesi et al., 2005).

A entrada no EF coincide com a transição entre os estágios pré-escolar e escolar. $\mathrm{Na}$ realidade, o ingresso da criança no ensino formal é justamente o evento que a coloca face a face com as tarefas de desenvolvimento do novo estágio - entre outras, ter sucesso no aprendizado acadêmico, formar laços de amizade com os coetâneos e aderir às normas da sociedade para conduta moral e comportamento prossocial (Masten \& Coatsworth, 1998).

Para superar os desafios das tarefas de desenvolvimento em perspectiva, a criança traz aquisições das fases anteriores, construídas predominantemente nas interações em casa e na escola, que vão alicerçar as novas conquistas (Marturano, 2008). Isto se dá num processo de continuidade e mudança nos padrões de comportamentos e relacionamentos. Continuidade, dentro do enfoque da ciência do desenvolvimento, refere-se aos padrões transferidos de uma situação anterior para uma nova. Quando esses padrões iniciais são validados pelas pessoas integrantes do novo contexto de interação, contribuem para adaptá-los às características da nova situação. Por outro lado, as mudanças nos padrões adaptativos requerem acomodações cognitivas e comportamentais do indivíduo, que apoiam ou consolidam uma nova direção adaptativa (Aspesi et al., 2005).

Esse processo adaptativo não se restringe às variáveis da criança. Variáveis da família e da escola, bem como outras variáveis do contexto no qual a criança está inserida, também exercem papel importante neste processo. No que se refere à família, recursos como práticas educativas positivas, estabelecimento de regras, estabilidade, o suporte à autonomia, o envolvimento dos pais nas atividades escolares dos filhos e a oferta de atividades socioculturais enriquecedoras durante os anos do EF beneficiam o bom desempenho escolar, sociabilidade na sala de aula, auto-regulação e percepção de controle por parte da criança. Em contraste, práticas educativas pobres, excesso de conflitos na família e um vínculo afetivo frágil entre pais e filhos favorecem o desenvolvimento de problemas emocionais e comportamentais (Marturano, 2008; Marturano \& Loureiro, 2003).

A escola, por sua vez, pela qualidade dos seus serviços prestados influencia a experiência escolar e, consequentemente, a trajetória de vida da pessoa. Nesse sentido, Morales e Guerra (2006) destacam a importância do suporte oferecido pela escola, principalmente pelo professor, uma vez que as experiências sócio-emocionais da criança na escola exercem influência no seu interesse em aprender, no engajamento nas atividades pedagógicas e, consequentemente, no desempenho acadêmico. Além disso, Marturano e Loureiro (2003) 
acrescentam que o acesso à educação básica e as trocas interpessoais que a escola proporciona possibilitam o desenvolvimento de um repertório diversificado de estratégias adaptativas para enfrentar os desafios da vida em sociedade. Deste modo, as experiências vivenciadas na escola afetam a formação do autoconceito e da autoestima da criança. Além disso, o sucesso escolar promove a permanência mais prolongada no sistema educacional, aumentando assim a abertura de oportunidades e, consequentemente, a probabilidade de trajetórias de vida mais favoráveis.

Como exemplo de variáveis contextuais, o nível socioeconômico do local onde a criança vive repercute no nível de exposição a estressores cotidianos. Segundo Morales e Guerra (2006), comunidades que apresentam altas taxas de pobreza se tornam uma fonte de estresse adicional para as famílias, podendo comprometer o desenvolvimento da criança. Alunos de escolas de regiões de baixo nível socioeconômico apresentam maiores níveis de estressores cotidianos por enfrentarem com maior frequência uma série de problemas, como por exemplo exposição à violência presente na vizinhança, moradia inadequada e desemprego dos pais (Amone-P'Olak et al., 2009; Escobar et al., 2013; Evans \& English, 2002).

A avaliação do funcionamento adaptativo na infância pode ser compreendida em termos de competência e disfunção. A competência é o indicador que avalia o grau em que um indivíduo é capaz de resolver de forma eficiente as tarefas de desenvolvimento e os desafios presentes no seu ambiente, resultando numa boa adaptação e não necessariamente num desempenho excelente. Por sua vez, problemas no funcionamento adaptativo ou disfunções referem-se à dificuldade recorrente em manter comportamentos de autocontrole (GardinalPizato, Marturano, \& Fontaine, 2014; Masten \& Coatsworth, 1998).

A competência é resultado de complexas interações entre a criança e seu ambiente. Sendo assim, as capacidades da criança e a natureza dos contextos em que ela vive influenciarão a competência. Do mesmo modo, as competências também se modificam à medida que o contexto muda ou a criança se desenvolve e se modifica (Masten \& Coatsworth, 1998). Como destacam Marturano e Ferreira (2004), o conceito de competência tem um caráter coconstrutivo e transacional, isto é, o indivíduo participa de forma ativa no desenvolvimento das competências necessárias ao cumprimento das tarefas exigidas pelo meio, ao mesmo tempo que depende do suporte oferecido pelos diversos sistemas sociais em que está inserido, tais como família e escola.

Dada a sua relevância para as tarefas de desenvolvimento da idade escolar, os domínios acadêmico e social têm sido incluídos nas pesquisas sobre competência infantil nos anos do EF (Chen, Huang, Chang, Wang, \& Li, 2010; Correia-Zanini, 2013). A competência no domínio 
acadêmico em geral é estimada por provas objetivas de habilidades escolares e avaliação do professor (Correia-Zanini, 2013). No que tange ao domínio social, a competência é frequentemente operacionalizada por meio do constructo habilidades sociais, que compreende um conjunto de classes de comportamentos apresentados pelo indivíduo em situações sociais que favorecem um relacionamento saudável e produtivo com as demais pessoas e implicam em algum controle das próprias emoções (Gardinal-Pizato et al., 2014).

Del Prette e Del Prette (2003) apontam que várias pesquisas têm incluído os déficits de habilidades sociais entre os fatores de risco para problemas comportamentais e emocionais, enquanto um repertório socialmente habilidoso vem sendo identificado como fator de proteção. São exemplos de classes de habilidades sociais a assertividade, solução de problemas interpessoais, cooperação, empatia, expressividade emocional e habilidades sociais acadêmicas (Del Prette \& Del Prette, 2005; Gardinal-Pizato et al., 2014).

Ao passo que o conceito de competência em escolares é usualmente acessado por meio de indicadores de desempenho acadêmico e social, disfunções têm sido operacionalizadas por meio do termo ajustamento comportamental que, por sua vez, está associado a dois fatores amplos: comportamentos externalizantes e internalizantes. Os comportamentos externalizantes incluem problemas com atenção, auto-regulação e comportamentos antissociais e agressivos. Já os comportamentos internalizantes incluem depressão, ansiedade, isolamento, sentimentos de inferioridade e queixas somáticas (Achenbach \& Edelbrock, 1979).

A partir do exposto até o momento, podemos conceber a transição para o EF como um momento instigador de processos desenvolvimentais, em que a criança se depara com tarefas desafiadoras que exigem dela um trabalho de adaptação, isto é, de desenvolvimento de novas competências através de processos de continuidade e mudança nos seus padrões de comportamentos e relacionamentos. Além disso, experiências vividas nessa transição podem ter influência na trajetória futura da criança na escola (Marturano et al., 2009). Pesquisas mostram que o desempenho acadêmico e a qualidade das relações interpessoais no início do EF predizem progresso escolar e ajustamento nos anos posteriores (Buhs, Ladd, \& Herald, 2006; Entwisle \& Alexander, 1998; Hamre \& Pianta, 2001; Hughes \& Kwok, 2007; Ladd \& TroopGordon, 2003; Silver, Measelle, Armstrong, \& Essex, 2010).

Enfim, partindo da concepção de trajetória como uma sequência de eventos que compõem o curso de vida do indivíduo, desenhada pela forma como se organizam as interações entre um estágio e outro, pelo modo como se estabelecem os elos do funcionamento psicológico entre os estágios e pela forma como se constroem as interações entre o indivíduo e o seu 
contexto (Aspesi et al., 2005), a entrada para o EF impacta não só a trajetória escolar do indivíduo, mas repercute na sua trajetória de vida como um todo.

\subsection{A criança no primeiro ciclo do EF em uma perspectiva de exposição a estressores cotidianos}

Os desafios do ingresso no EF não se limitam à exigência das tarefas de desenvolvimento da idade escolar. A mudança de nível escolar carreia tarefas adaptativas importantes, que se fazem ainda mais desafiadoras quando a criança não frequentou a educação infantil (EI), ou quando, em uma situação muito frequente no sistema escolar brasileiro, mesmo tendo passado pela EI, ela precisa mudar de escola para ingressar no EF (Marturano, 2008; Trivellato-Ferreira \& Marturano, 2008).

Dentre as demandas que são apresentadas para a criança na entrada para o EF se sobressaem as de lidar com um novo ambiente, relacionar-se com adultos ainda desconhecidos, conquistar aceitação em um novo grupo de iguais e atender às exigências do seu papel de estudante, traduzidas nas expectativas dos adultos e formalizadas por meio de avaliações periódicas de progresso (Marturano, 2008; Trivellato-Ferreira \& Marturano, 2008). Essa diversidade de novas demandas requer um trabalho de adaptação, isto é, de desenvolvimento de novas competências para lidar com a imprevisibilidade e as incertezas inerentes à mudança (Aspesi et al., 2005).

Porém, apesar de a transição ser um momento propício para o desenvolvimento de competências, essas incertezas e imprevisibilidades geram estresse e ansiedade na criança (Marturano, 2008). Em outras palavras, em momentos de transição escolar, com o aumento de exposição da criança à imprevisibilidade, pode-se supor também um risco de aumento da sintomatologia de estresse. Lipp e Lucarelli (2008) definem estresse como a reação do organismo composta por componentes físicos (dores de cabeça, dores abdominais, alterações do apetite, diarreia, gagueira, etc.) e/ou psicológicos (desânimo, ansiedade, birra, choro excessivo, terror noturno, etc.) frente a qualquer estímulo que o irrite, amedronte e/ou o faça feliz, isto é, qualquer fato novo que exija adaptação. Segundo estas autoras, o estresse infantil apresenta sintomas semelhantes aos dos adultos e pode ser avaliado de acordo com o conjunto de sintomas que apresentam e a fase de evolução destes: fases de Alerta ou Alarme, Defesa ou Resistência, Quase-exaustão e Exaustão, considerada a fase mais aguda do estresse. 
A literatura referente à investigação do estresse diferencia três tipos de estressores: eventos de vida, estressores crônicos e aborrecimentos cotidianos, conhecidos na literatura internacional como “daily hassles”. Os eventos de vida se referem às situações excepcionais, traumáticas, incontroláveis e imprevisíveis que impactam a vida da pessoa, exigindo dela uma certa adaptação. Já os estressores crônicos são os resultados de danos progressivos de aspectos físicos e sociais adversos presentes no ambiente imediato, levando a uma série de privações e desvantagens que implicam em ameaças contínuas e mudanças para o indivíduo. Por fim, "daily hassles" são as demandas irritantes, frustrantes e perturbadoras que em alguma medida caracterizam as transações diárias com o ambiente, podendo afetar o bem-estar físico e emocional de adultos, adolescentes e, inclusive, crianças (Bridley \& Jordan, 2012; Escobar et al., 2013; Kanner, Coyne, Schaefer, \& Lazarus, 1981).

Segundo Bridley e Jordan (2012), muitos estudos têm afirmado que essas tensões cotidianas detêm maior poder de avaliação de estresse do que os eventos de vida na predição de sintomas e disfunções psicológicos de crianças e adultos. Na infância, essas tensões cotidianas estão presentes em situações relacionadas à saúde, à escola e à família. Adoecimentos, procedimentos médicos e preocupações com a imagem corporal são exemplos de tensões relacionadas à saúde. No contexto escolar, as situações estressantes abarcam as demandas acadêmicas, notas baixas, problemas de relacionamento com os professores e com os colegas, mau desempenho nos esportes, dentre outros. Por fim, no âmbito familiar estes aborrecimentos estão associados a dificuldades financeiras, falta de supervisão dos pais, conflitos com os irmãos ou entre os pais, dentre outros (Escobar et al., 2013; Vanaelst, De Vriendt, Huybrechts, Rinaldi, \& De Henauw, 2012).

Recentemente, Escobar et al. (2013) realizaram uma investigação no contexto espanhol com uma amostra composta por 6078 escolares, com idades entre 8 e 12 anos, com o objetivo de identificar variáveis que poderiam contribuir para presença de tensões percebidas pelas crianças no seu cotidiano. Estes pesquisadores avaliaram estressores relacionados à saúde, à escola e à família para compor uma medida única para presença de estressores cotidianos. Nos resultados, crianças mais jovens apresentaram maiores níveis de tensões cotidianas e esta relação variou entre as escolas, indicando que a escola modera o efeito da idade nos estressores cotidianos.

De particular interesse para o presente estudo são as tensões cotidianas referentes ao contexto escolar, lugar onde a criança passa grande parte do seu tempo e que é concebido por muitas crianças como uma fonte importante de tensões cotidianas (Barrett \& Heubeck, 2000; 
Eriksson \& Sellström, 2010; Rende \& Plomin, 1992).Os relacionamentos com os colegas e/ou com professores são, por exemplo, importantes fontes de estresse cotidiano para crianças durante seu primeiro ano no EF (Marturano, 2008; Marturano et al., 2009; Marturano \& Gardinal, 2008; Rende \& Plomin, 1992; Stasiak, 2010).

No entanto, uma recente revisão da literatura sobre estudos que investigaram o estresse infantil associado a demandas presentes no contexto escolar do EF resultou em nove artigos, o que sinaliza uma escassez de investigações neste campo de estudo. Essa revisão foi realizada em novembro de 2014 e buscou estudos empíricos publicados em forma de artigos, realizados com crianças de seis a 12 anos, nos idiomas inglês, português e espanhol, sem restrições para o ano de publicação, em quatro bases de dados: Lilacs (Literatura Latino-Americana em Ciências da Saúde), Scielo (Scientific Eletronic Library Online), Pubmed (US National Library of Medicine) e PsycInfo (American Psychological Association). Os métodos de busca utilizados em cada base de dados se diferenciaram de modo que se adequassem aos recursos de seleção disponíveis e favorecessem a captação de um maior número de artigos que atendessem ao objetivo dessa revisão. Deste modo, nas bases de dados Lilacs e Scielo foram utilizados os mesmos cruzamentos de palavras: (escol\$ OR "ensino fundamental") AND (criança \$ OR alun\$ OR estudante\$ OR escolar\$) AND (estresse OR stress). Na PubMed utilizaram-se somente descritores, combinados da seguinte maneira: ("Stress, Psychological" OR "Stress, Physiological") AND (Child) AND (Schools). Na base PsycInfo, descritores e palavras foram assim combinados: descritores ("Physiological Stress" OR "Psychological Stress") AND palavras (school*).

Dentre os artigos resultantes, os estudos de Fletcher, Walls, Eanes e Troutman (2010), Hesketh et al. (2010), Hjern, Alfven e Östberg (2008) e Morales e Guerra (2006) avaliaram a ocorrência de diversas situações estressantes no contexto escolar para as crianças. No estudo de Fletcher et al. (2010) utilizou-se a medida de estresse escolar como indicador de competência escolar na investigação de sua associação à maneira como a mãe utiliza os seus próprios relacionamentos sociais para promover a socialização da criança na escola. Já nas pesquisas de Hesketh et al. (2010) e Hjern et al. (2008) foi investigada a associação do estresse escolar a queixas psicossomáticas. E, na investigação de Morales e Guerra, o objetivo principal foi investigar os efeitos múltiplos ou cumulativos do estresse oriundos de três contextos: escola, família e vizinhança.

Dois estudos abordaram a associação do estresse a uma demanda escolar específica. Lemes et al. (2003) abordaram somente o desempenho acadêmico e Escobar, Trianes, 
Fernández-Baena e Páez (2010) o relacionamento com os pares. Diferentemente, Jacobson, Riesch, Temkin, Kedrowski e Kluba (2011) realizaram uma investigação pelo método qualitativo de situações ocorridas no contexto escolar nas quais as crianças se sentiam inseguras e com medo.

Dentre os nove artigos encontrados nesta revisão de literatura, as únicas pesquisas que investigaram a ocorrência do estresse associado a demandas presentes no contexto escolar na transição para o EF foram as realizadas por Marturano e Gardinal (2008) e Marturano et al. (2009), ambas realizadas por um mesmo grupo de pesquisadores brasileiros. Além de investigarem a ocorrência de diversas situações possivelmente estressantes, estas pesquisas também examinaram o quanto estas situações foram percebidas como aborrecedoras pelas crianças.

Esses estudos fazem parte de um conjunto de pesquisas brasileiras realizadas na década passada, que investigaram aspectos do desenvolvimento das crianças na $1^{\text {a }}$ série do EF, sob o ponto de vista do estresse associado às demandas adaptativas da transição. Essas pesquisas se apoiaram em um esquema conceitual que considera três conjuntos de demandas adaptativas específicas: ajustar-se às mudanças na definição de papéis e comportamentos esperados; situarse na rede social ampliada; adequar-se às normas e regras, explícitas e implícitas, do novo contexto (Elias, 1989; Marturano, 2008).

As pesquisas foram guiadas pelas seguintes proposições: (a) o primeiro ano que a criança passa no EF é um momento particularmente estressante; (b) as tarefas adaptativas da transição constituem fontes de tensões cotidianas; (c) a criança perceberá mais tensões nos domínios da sua vida escolar que correspondem a tarefas adaptativas mais desafiadoras para ela. De acordo com essas proposições, haveria, então, uma relação inversa entre os níveis de competência e a percepção de tensões cotidianas na escola, e essa relação seria específica entre cada tarefa adaptativa e seu correspondente domínio de estresse. Por exemplo, crianças com dificuldades acadêmicas relatariam maior exposição a tensões cotidianas associadas ao seu papel de estudante. Crianças com habilidades sociais mais desenvolvidas estariam menos vulneráveis a tensões decorrentes da exigência de se situarem na rede social ampliada.

Ainda que sem previsão explícita no modelo, pode-se ainda supor (a) uma relação direta entre exposição ao estresse escolar e sintomas de estresse; (b) uma relação inversa entre competência e sintomas de estresse. Desse modo, crianças com menor repertório de habilidades acadêmicas e sociais, além de apresentarem maior percepção de estressores escolares, estariam em maior risco de também apresentarem mais sintomas de estresse. 
Dentre os estudos que investigaram empiricamente a transição do primeiro ano no EF, na perspectiva de tensões cotidianas, o de Trivellato-Ferreira e Marturano (2008) focalizou precursores de competência acadêmica e social, ajustamento, percepção de tensões cotidianas e sintomas de estresse, em alunos que ingressavam na $1^{a}$ série. No início do ano, setenta crianças foram avaliadas quanto ao nível intelectual, consciência fonológica, suporte familiar (práticas educativas e recursos promotores de desenvolvimento) e frequência à EI. No final do ano letivo, os professores avaliaram desempenho acadêmico, habilidades sociais e ajustamento comportamental das crianças; estas responderam a um teste de desempenho e relataram sintomas de estresse e percepção de estressores escolares.

Nos resultados, variáveis da criança e da família predisseram ajustamento, desempenho acadêmico e competência social, mas somente a frequência à EI predisse a percepção de estresse no final da $1^{\mathrm{a}}$ série. Associado a indicadores de maior competência acadêmica e social nas crianças com acesso prévio à EI, esse é um resultado que ressalta o potencial da EI para desenvolver habilidades precursoras de competência e atenuar o impacto da transição. Crianças com experiência prévia na EI mostraram menor estresse que crianças sem experiência. Elas também se saíram melhor nas avaliações de desempenho e em alguns itens de ajustamento e habilidades sociais avaliados pelo professor. Pesquisa subsequente confirmou essa influência positiva da EI sobre o desenvolvimento acadêmico e social no EF (Pereira, Marturano, Gardinal-Pizato, \& Fontaine, 2011).

Trivellato-Ferreira e Marturano (2008) encontraram correlação positiva entre percepção de tensões cotidianas na escola e sintomas de estresse. Encontraram também correlação negativa entre indicadores de desempenho e de estresse, porém com variações. Ao passo que os sintomas de estresse correlacionaram negativamente com o desempenho em teste objetivo (Teste de Desempenho Escolar), a percepção de tensões na escola correlacionou com uma avaliação de desempenho feita pelo professor.

Marturano et al. (2009) apresentaram um estudo conduzido em escolas públicas, com o objetivo de avaliar a intensidade do estresse associado ao cotidiano escolar na transição da $1^{\text {a }}$ série, bem como investigar associações entre desempenho, ajustamento e estresse em quatro domínios da vida escolar: desempenho, relação família-escola, relacionamentos com os pares e demandas não acadêmicas. Participaram 171 alunos iniciantes na $1^{\mathrm{a}}$ série e seus professores. Os instrumentos utilizados foram: Inventário de Estressores Escolares (IEE), Teste de Desempenho Escolar, Avaliação do Desempenho e do Ajustamento pelo Professor. 
Em relação ao primeiro objetivo, pelo menos $20 \%$ das crianças indicaram ter passado pela maioria das situações apresentadas; além disso, identificaram grande parte das situações como fontes de estresse moderado a alto, o que confirma a visão da escola como fonte de estresse cotidiano (Kraag, Zeegers, Kok, Hosmane, \& Abu-Saad, 2006). As crianças apontaram o domínio do relacionamento com os companheiros como o mais estressante. Em relação a esse domínio, o do desempenho acadêmico foi percebido como significativamente menos estressante, sugerindo que a tarefa relacionada aos papéis esperados é percebida como menos exigente.

Em relação ao segundo objetivo de seu estudo, Marturano et al. (2009) constataram que o estresse no domínio do desempenho escolar e no domínio da relação família-escola foi negativamente correlacionado a desempenho e ajustamento. A relação entre estresse escolar e ajustamento já havia sido demonstrada em alunos da $1^{\text {a }}$ série por Rende e Plomin (1992) e em séries mais avançadas, por diversos autores (Barrett \& Heubeck, 2000; Morales \& Guerra, 2006; Santa Lucia et al., 2000). Os achados de Buhs et al. (2006) e Ladd e Troop-Gordon (2003) também permitiram inferir uma associação negativa entre ajustamento e percepção de tensões no âmbito do relacionamento com os pares. Estes estudos encontraram correlação positiva entre problemas de comportamento avaliados pelos professores na pré-escola e exposição a tensões nos relacionamentos com os colegas, tais como vitimização e rejeição pelos pares, avaliada concomitantemente ou em anos subsequentes. Já a associação entre percepção de estresse e desempenho não tinha uma comprovação empírica até então, havendo apenas evidência indireta (Ladd, Birch, \& Buhs, 1999).

No estudo prospectivo conduzido por Marturano e Gardinal (2008) foram investigadas associações entre indicadores de desempenho/ comportamento, na EI e na $1^{\mathrm{a}}$ série, e o estresse cotidiano da $1^{\text {a }}$ série, tal como percebido pelas crianças nos domínios de desempenho, relação família-escola, relacionamentos com os pares e demandas não-acadêmicas. Participaram 110 crianças e seus professores. Os instrumentos utilizados foram: IEE, Teste de Desempenho Escolar, uma sondagem de leitura, um formulário para o professor avaliar o desempenho acadêmico e um questionário para o professor avaliar o comportamento do aluno em relação à tarefa escolar, ao professor e aos colegas. Foram feitas duas coletas de dados, no segundo semestre da EI e no segundo semestre da $1^{\text {a }}$ série. Nos resultados, o melhor desempenho na EI ou na $1^{\mathrm{a}}$ série foi associado a menos estresse nos domínios do desempenho e da relação famíliaescola. Além disso, crianças que na $1^{\mathrm{a}}$ série foram avaliadas pelo professor com nível alto de 
problemas no relacionamento com os colegas relataram estresse mais elevado em todos os domínios do cotidiano escolar, quando comparadas a crianças com nível baixo de problemas.

Gardinal-Pizato (2010) estabeleceu a estrutura fatorial do IEE, instrumento empregado nas pesquisas sobre tensões cotidianas no EF. Em uma amostra de 294 alunos do $3^{\circ}$ ano do EF, por meio de análise fatorial exploratória e confirmatória, encontrou uma estrutura com dois fatores. O primeiro contém itens referentes ao posicionamento dos adultos em relação ao desempenho acadêmico da criança, tais como A professora mandou bilhete para meus pais quando eu não estava aprendendo direito e Minha mãe (ou meu pai) brigou comigo na hora da lição de casa. O segundo compreende itens de relacionamentos na escola, como Meus colegas de classe bateram em mim, A professora não se importou comigo e Um adulto chamou a minha atenção através de grito, xingamento, beliscões.

Essa estrutura fatorial sugere que, de acordo com a percepção das crianças, as fontes de tensões cotidianas no início do EF se diferenciam em dois domínios - o do seu papel de estudante e o dos relacionamentos na escola. Empiricamente, apenas o primeiro apresentou correspondência estrita entre a percepção da criança e indicadores objetivos de realização da tarefa adaptativa, conforme indicam os estudos citados anteriormente. Em contrapartida, como apontam Marturano et al. (2009), ele é avaliado como significativamente menos estressante, sugerindo que a tarefa relacionada aos papéis esperados é percebida como menos exigente que a de inserção na rede social ampliada.

Rende e Plomin (1992) já tinham encontrado na $1^{\text {a }}$ série menor intensidade de estresse no domínio acadêmico que no domínio interpessoal, ao passo que em séries mais avançadas as crianças relatam o domínio do desempenho como um dos mais estressantes (Kraag et al., 2006). Com base nesses resultados, Marturano e Gardinal-Pizato (2010) realizaram um estudo transversal para explorar duas hipóteses: (a) tensões cotidianas nos relacionamentos têm maior impacto na $1^{\mathrm{a}}$ série, por ser uma fase de inserção em novo grupo de iguais e de aprendizado das regras do novo contexto; (b) tensões cotidianas relacionadas ao papel de estudante são maiores na $2^{\mathrm{a}}$ série, quando há maior exigência de desempenho e história prévia mais extensa de exposição a demandas acadêmicas. $\mathrm{O}$ estudo explorou também a influência da escola na percepção de estresse.

Os participantes foram 122 crianças de ambos os sexos, que frequentavam a $1^{\mathrm{a}}$ ou a $2^{\mathrm{a}}$ série em escolas públicas; o instrumento utilizado foi o IEE com a estrutura de dois fatores. Ao contrário do que se esperava, a percepção de tensões cotidianas relacionadas à rede social foi maior nos alunos da $2^{\text {a }}$ série. Em contrapartida, a percepção de estressores em ambos os 
domínios foi inversamente associada à qualidade da escola, avaliada por educadores e psicólogos em procedimento específico.

A literatura abordada até aqui expôs a associação entre estresse e demandas adaptativas sociais e acadêmicas no início do EF.A presença de sintomas de estresse e a percepção de estressores escolares neste momento podem sinalizar dificuldades diante de algumas demandas típicas desta fase de transição. Pelos resultados das pesquisas, verifica-se a confirmação de algumas previsões feitas a partir do modelo teórico. Foi encontrada uma relação inversa entre os níveis de competência e a percepção de tensões cotidianas na escola, assim como entre competência e sintomas de estresse, ainda que esta última associação tenha sido investigada em apenas um estudo, o de Trivellato-Ferreira e Marturano (2008). As pesquisas confirmaram também uma relação específica entre tarefa adaptativa e seu correspondente domínio de estresse, porém somente em relação à tarefa de adequar-se ao papel de estudante. Em contrapartida, persistem questões a serem melhor investigadas.

\subsection{Justificativa}

Os resultados das pesquisas revistas nos parágrafos precedentes em geral são consistentes com a concepção do $1^{\circ}$ ano do EF como uma transição potencialmente estressante para as crianças. No entanto, como assinala Correia-Zanini (2013), o contexto no qual estas pesquisas foram realizadas já não corresponde integralmente, nos dias de hoje, à realidade da experiência da transição para as crianças. Esta diferença se deve à implantação do EF de nove anos, instituído pela Lei de Diretrizes e Bases da Educação Nacional (LDB 9394/96) e tornado obrigatório em todo o país a partir de 2010.

Com o EF de nove anos, as crianças ingressam nesse nível de ensino um ano mais jovens que aquelas que frequentaram o EF de oito anos e que foram participantes das pesquisas prévias sobre a transição. A média de idade das crianças do $1^{\circ}$ ano é de aproximadamente seis anos, e não de sete como na antiga $1^{\mathrm{a}}$ série. Essa diferença etária, dadas as suas implicações desenvolvimentais, por si só justifica a replicação dos estudos previamente conduzidos sobre a transição.

Além disso, persistem questões ainda não suficientemente investigadas, como a da relação inversa entre competência e sintomas de estresse, a do curso desenvolvimental das percepções de estresse associado às diferentes tarefas adaptativas nos primeiros anos do EF e a da influência da escola nos indicadores de estresse. 
Este estudo é um recorte da pesquisa de doutorado intitulada "Um estudo prospectivo sobre o percurso escolar de crianças nos primeiros anos do Ensino Fundamental" (CorreiaZanini, 2013). O objetivo maior da pesquisa mais ampla foi investigar o percurso escolar de crianças nos três anos iniciais do EF, nos domínios do desempenho acadêmico, habilidades sociais, sintomas de estresse, percepção de estresse e problemas de comportamento; levou-se em conta na predição desse percurso o nível intelectual, os recursos do ambiente familiar, a frequência à EI e as características da escola de EF, tais como a classificação no Índice de Desenvolvimento da Educação Básica - IDEB e a localização no município (centro, periferia e entre centro e periferia).

Nos resultados, foram de particular interesse para o presente estudo aqueles referentes ao estresse no $1^{\circ}$ e no $2^{\circ}$ ano do EF. No $1^{\circ}$ ano, verificou-se que a maioria dos alunos (58\%) apresentou sintomas de estresse e mais de $40 \%$ se encontravam na Fase de Quase-Exaustão. Em média, os alunos apresentaram 35\% dos sintomas avaliados, sendo os de ordem psicológica e física os mais presentes. A presença de sintomas de estresse correlacionou significativa e moderadamente com a percepção de tensões cotidianas na escola. Também obteve correlação negativa com habilidades sociais, competência acadêmica, desempenho acadêmico e potencial cognitivo.

No que se refere a associações entre características das escolas e das crianças, não foram encontradas associações com sintomas de estresse. Em contrapartida, identificaram-se associações com a percepção de estressores escolares: quanto maior o índice no IDEB, menor a percepção da escola como fonte de estresse; além disso, alunos das escolas situadas na periferia da cidade perceberam suas escolas como mais estressantes, em relação aos alunos da escola central e de escolas situadas entre o centro e a periferia.

No $2^{\circ}$ ano, os resultados foram semelhantes, com uma particularidade: houve um aumento no percentual de crianças com sintomas de estresse, de $58 \%$ para $74 \%$. Esse resultado aparentemente contradiz a visão do $1^{\circ}$ ano como um momento crucial da transição de vida configurada pelo ingresso no EF, porque, se assim fosse, esperar-se-ia uma diminuição e não um aumento no número de crianças estressadas à medida que avança a escolaridade. Pode-se então perguntar se o desafio das demandas novas estaria ultrapassando os recursos de enfrentamento das crianças, o que resultaria em acumulação da sintomatologia de estresse à medida que o tempo passa. Em uma perspectiva diferente, pode-se supor que a transição do ingresso no EF se prolonga além do $1^{\circ}$ ano, com demandas diversas a cada ano. A respeito de demandas diferentes, pode-se lembrar, por exemplo, que no $2^{\circ}$ ano do EF os alunos passam por 
duas avaliações coletivas da chamada Provinha Brasil, o que não acontece no $1^{\circ}$ ano (http://provinhabrasil.inep.gov.br).

Os resultados de Correia-Zanini (2013) referentes ao estresse no $1^{\circ}$ ano do EF, além de confirmarem algumas tendências sugeridas em pesquisas prévias, também avançam ao mostrar um cenário de elevado estresse em crianças tão jovens. Tendo em vista as implicações desses resultados para o bem estar e a saúde das crianças, a lacuna apresentada na literatura empírica sobre o estresse da transição no contexto do EF de nove anos e as questões ainda não suficientemente investigadas, conforme apontado atrás, propôs-se o presente estudo, no qual se utilizou parte dos dados coletados por Correia-Zanini. O foco da investigação aqui relatada é o estresse do $2^{\circ}$ ano do EF, que do ponto de vista da idade dos alunos corresponde à antiga $1^{\mathrm{a}}$ série. Desse modo, espera-se contribuir para a compreensão do fenômeno no EF de nove anos. Também se espera agregar informações para o esclarecimento de pontos ainda obscuros, como a relação inversa entre competência e sintomas de estresse, o curso desenvolvimental das percepções de estresse, sua associação com as diferentes tarefas adaptativas nos primeiros anos do EF e a influência da escola nos indicadores de estresse. Espera-se, por fim, lançar alguma luz sobre o preocupante achado dos altos índices de sintomas de estresse, identificados já no $1^{\circ}$ ano e exacerbados no $2^{\circ}$ ano.

\subsection{Objetivos}

\subsubsection{Objetivos Gerais}

- Analisar a relação entre competência e sintomas de estresse na transição do $1^{\circ}$ ano do $\mathrm{EF}$, relatada previamente em um único estudo empírico.

- Investigar prospectivamente as associações entre indicadores de cumprimento das tarefas adaptativas da transição para o EF, avaliados $1^{\circ}$ ano, e manifestações de estresse avaliadas no $2^{\circ}$ ano do EF, expressas em sintomas de estresse e percepções de estresse. - Identificar, de forma exploratória, o curso desenvolvimental dos sintomas de estresse e das percepções de estresse nos anos iniciais do EF.

- Investigar, de forma exploratória, a influência da escola nos indicadores de estresse.

- Explorar modelos explicativos para os sintomas de estresse e a percepção de estressores escolares apresentados pelas crianças no $2^{\circ}$ ano, tendo como preditores variáveis da criança e da escola avaliadas no $1^{\circ}$ ano. 


\subsubsection{Objetivos Específicos}

- Comparar alunos do $1^{\circ}$ ano avaliados com sintomas de estresse e sem sintomas de estresse nas variáveis da criança avaliadas no mesmo ano: (a) percepção de estresse na escola; (b) desempenho acadêmico; (c) competência acadêmica; (d) habilidade sociais; (e) problemas de comportamento. Este objetivo específico está relacionado ao objetivo geral de investigar a relação entre sintomas de estresse e competências.

- Investigar possíveis associações entre indicadores de estresse - sintomas de estresse e percepção de estressores escolares nos dois fatores (relacionado ao papel de estudante e às relações interpessoais) - avaliados em crianças no $2^{\circ}$ ano do EF e as variáveis de competência e ajustamento da criança avaliadas no $1^{\circ}$ ano: (a) desempenho acadêmico; (b) competência acadêmica; (c) habilidades sociais; (d) problemas de comportamento. Este objetivo específico está relacionado ao objetivo geral de examinar prospectivamente a associação entre cumprimento das tarefas adaptativas da transição e estresse.

- Comparar os níveis de estresse e de percepção de estressores escolares nos dois fatores (relacionado ao papel de estudante e às relações interpessoais) dos alunos no $1^{\circ}$ e no $2^{\circ}$ ano do EF a fim de investigar a tendência desenvolvimental das manifestações de estresse nos anos iniciais do EF.

- Investigar possíveis associações entre indicadores de estresse da criança avaliados no $2^{\circ}$ ano e características da escola (pontuação no IDEB e localização) com a finalidade de sondar a influência da escola nos indicadores de estresse dos seus alunos.

- A fim de explorar modelos explicativos para manifestações de estresse no $2^{\circ}$ ano:

a) verificar quais das seguintes variáveis da criança e da escola, avaliadas no $1^{\circ}$ ano, predizem variação, no $2^{\circ}$ ano, nos níveis de sintomas de estresse e na percepção de estressores escolares relacionados ao papel de estudante e às relações interpessoais: desempenho acadêmico; competência acadêmica; habilidade sociais; problemas de comportamento; presença de sintomas de estresse; percepção de estresse na escola; pontuação da escola no IDEB; localização da escola.

b) investigar a importância relativa de cada variável preditora, em presença das demais. 


\section{MÉTODO}

\subsection{Considerações éticas}

O estudo atende as normas da Resolução n ${ }^{\circ}$ 196/96 do CONEP e ao disposto na Resolução no 016/2000 do Conselho Federal de Psicologia. É parte de projeto aprovado pelo Comitê de Ética em Pesquisa (CEP) da Faculdade de Filosofia, Ciências e Letras de Ribeirão Preto (Processo CEP- FFCLRP n ${ }^{\circ}$ 528/2010.1.1794.59.2, ANEXO A). A participação da autora, que se incumbiu do recorte descrito nesta pesquisa, foi comunicada ao CEP logo após a aprovação no processo seletivo para o Mestrado em Psicologia da Faculdade de Filosofia, Ciências e Letras de Ribeirão Preto.

\subsection{Participantes}

A amostra do estudo foi formada com base no banco de dados da pesquisa de CorreiaZanini (2013), que compreende 186 participantes. Desse total, foram selecionadas 157 crianças, sendo 85 meninos e 72 meninas, que atendiam ao critério de experiência prévia de dois anos na EI, de modo a uniformizar a amostra do estudo quanto a esse fator.

A idade média dos participantes no início da pesquisa era seis anos e 10 meses $(\mathrm{DP}=$ quatro meses). Todos estavam matriculados no $1^{\circ}$ ano do EF em escolas municipais situadas em uma cidade do interior de São Paulo com aproximadamente 111 mil habitantes. Também participaram do estudo seus respectivos professores no $1^{\circ}$ ano do EF, num total de 25 .

\subsection{Local}

Os dados foram coletados em sete dentre as 15 escolas municipais que oferecem EF, situadas em diferentes regiões do município: uma no centro, duas próximas ao centro e quatro na periferia.

\subsection{Materiais, Instrumentos e Fonte de Dados}

\section{Ficha de Identificação dos Participantes}

Ficha elaborada por Correia-Zanini (2013), em que são levantados os dados pessoais 
dos participantes.

\section{Ficha de identificação das Escolas}

Ficha elaborada por Correia-Zanini (2013), em que são identificadas a pontuação da escola no IDEB e a localização da escola (centro, quando localizada no centro da cidade; entre centro e periferia, quando se situa em bairro no entorno do centro; periferia, quando mais distante do centro e mais próxima da zona rural que as escolas situadas entre centro e periferia). Escala de Stress Infantil (ESI)

A ESI tem como objetivo identificar a frequência com que crianças de seis a 14 anos experimentam sintomas de estresse e quais tipos de reação caracterizam tais sintomas (Lipp \& Lucarelli, 2008). A escala é composta por 35 itens, cada qual acompanhado de uma escala analógica do tipo Likert, em forma de círculo dividido em quadrantes. A pontuação corresponde ao número de quadrantes do círculo que a criança pintou. Não pintar o círculo corresponde a nunca acontece - 0 ponto; pintar uma parte - acontece um pouco - 1 ponto; pintar duas partes - acontece às vezes - 2 pontos; pintar três partes - acontece quase sempre - 3 pontos e pintar quatro partes - acontece sempre - 4 pontos. A soma de pontos de todos os itens resulta no escore total de sintomas apresentados pela criança. Com este escore também é possível identificar a fase do estresse: de 0 a 39,5 - sem estresse; de 39,6 a 59,4 - fase de alerta; de 59,5 a 79,4 pontos - fase de resistência; 79,5 a 99,3 ou sete círculos com todas as partes pintadas fase de quase exaustão; acima de 99,3 - fase de exaustão. No presente estudo, além do escore total de sintomas, utilizou-se uma classificação dicotômica entre as pontuações 39,5 e 39,6 para discriminar crianças sem sintomas de estresse e crianças com sintomas nas demais fases do estresse.

\section{Inventário de Estressores Escolares (IEE)}

O IEE visa investigar situações perturbadoras ou irritantes relacionadas à vida escolar, em quatro domínios: desempenho escolar, relação família-escola, relação com os pares e outras demandas da vida escolar (Marturano \& Gardinal, 2008; Trivellato-Ferreira \& Marturano, 2008). Apresentado individualmente à criança, é composto por trinta itens. Para cada situação apresentada, a criança responde se aquilo aconteceu com ela durante o ano letivo; caso tenha acontecido, informa ainda o quanto a situação a aborreceu. Para a medida de exposição aos estressores, atribui-se valor zero ao item que, segundo a criança, não ocorreu, e um para a situação que ocorreu. Para a medida de impacto, cada item ocorrido recebe o acréscimo de zero, um, dois ou três pontos, de acordo com a intensidade do efeito relatado pela criança em uma escala de quatro pontos: nada, só um pouco, mais ou menos, muito. Marturano e Gardinal 
(2008) reportam índices adequados de consistência interna (alfa igual a 0,72 para exposição e 0,84 para impacto); o escore de impacto mostrou correlação positiva com sintomas de estresse (Trivellato-Ferreira \& Marturano, 2008) e estabilidade entre avaliações feitas com oito meses de intervalo (Marturano et al., 2009).

No presente estudo, o IEE foi utilizado com a estrutura fatorial de duas dimensões identificada por Gardinal-Pizato (2010) e revisada por Correia-Zanini (2013): (a) estressores associados ao papel de estudante, com 10 itens referentes ao desempenho escolar, à relação família-escola e ao professor; (b) estressores derivados das relações interpessoais na escola, com 7 itens do relacionamento com os pares e com adultos.

\section{Sistema de Avaliação de Habilidades Sociais}

Utilizou-se a adaptação brasileira do Social Skills Rating System (SSRS-BR) - versão para Professores (Bandeira, Del Prette, Del Prette, \& Magalhães, 2009). O questionário destinado aos professores compreende três escalas: habilidades sociais, com cinco fatores (cooperação com pares, asserção positiva, responsabilidade/cooperação, auto-defesa e autocontrole); problemas de comportamento, composta por dois fatores (internalizantes e externalizantes); competência acadêmica, composta por nove itens. Para avaliar a frequência de habilidades sociais e de comportamentos problemáticos são utilizadas três alternativas de resposta: "nunca" (0), "algumas vezes" (1) e "muito frequente" (2). Para medir competência acadêmica os professores comparam o desempenho da criança com o dos demais alunos da mesma classe, havendo cinco alternativas de resposta: “entre os $10 \%$ piores" (1), "entre os $20 \%$ piores" (2), "entre os $40 \%$ médios" (3), "entre os $20 \%$ bons" (4) e "entre os $10 \%$ ótimos" (5). O escore total de cada escala ou fator é o resultado da soma obtida nos itens correspondentes. Bandeira et al. (2009) relatam índices satisfatórios de consistência interna e estabilidade temporal para a adaptação brasileira das escalas. A estrutura fatorial utilizada neste estudo foi a obtida por meio de Análise Fatorial Confirmatória realizada por Correia-Zanini (2013).

\section{Provinha Brasil 2009}

A avaliação denominada Provinha Brasil foi elaborada pelo Instituto Nacional de Estudos e Pesquisas Educacionais Anísio Teixeira (INEP) e tem como objetivo diagnosticar o nível de alfabetização das crianças matriculadas no $2^{\circ}$ ano do EF das escolas públicas brasileiras. Utilizamos a avaliação referente ao ano de 2009. Ela é composta por um exemplo de questão que possibilita ensinar aos alunos como deverão responder ao teste e por outras 24 questões de múltipla escolha formuladas para avaliar o desempenho. As questões avaliativas são sequenciadas em níveis crescentes de exigência de habilidades, desde as mais básicas até 
as mais avançadas. As questões são de três tipos: Tipo 1 - Questões cujos comandos e alternativas precisam ser totalmente lidos pelo aplicador; Tipo 2 - Questões nas quais o aplicador lê apenas os comandos; Tipo 3 - Questões em que o aplicador lê apenas a orientação inicial para avisar aos alunos que terão que ler sozinhos o texto, os enunciados e as alternativas. Cada questão acertada recebe um ponto e a pontuação total é referente à soma dos itens que a criança acertou, variando portanto entre 0 e 24 (INEP, 2009).

\section{Índice de Desenvolvimento da Educação Básica (IDEB)}

O índice foi criado pelo INEP no ano de 2007 com a finalidade de avaliar e estabelecer metas para a educação básica brasileira. É meta do INEP que todas as escolas brasileiras, até o ano de 2022, obtenham média igual ou superior a 6 pontos no IDEB, o que indicaria um sistema educacional comparável aos de países desenvolvidos (INEP, 2009).

Esta avaliação ocorre a cada dois anos, no término do ano letivo. O IDEB é composto por dois indicadores: proficiência e fluxo. O desempenho médio dos alunos é medido por avaliações promovidas pelo Instituto, no caso de escolas municipais a Prova Brasil, ao final das etapas de ensino ( $5^{\circ}$ e $9^{\circ}$ ano do EF e $3^{\mathrm{a}}$ ano do Ensino Médio). O fluxo escolar é calculado com base no índice de aprovação escolar obtido por meio do Censo Escolar. Estes índices podem ser acessados por meio de consulta ao site do INEP, http://portalIDEB.inep.gov.br. Os dados utilizados neste trabalho correspondem ao escore total do IDEB referente ao ano de 2009, avaliação que antecedeu a coleta de dados das crianças no $1^{\circ}$ ano do EF, em 2010.

\subsection{Procedimento de coleta de dados}

O projeto-mãe foi submetido à Secretária da Educação do município, que autorizou sua execução. Os dados foram coletados em sete dentre as 15 escolas municipais que oferecem EF. A seleção das escolas foi por conveniência realizada juntamente com técnicos da secretaria de educação do município, visando representar diferentes regiões: uma escola na região central, duas próximas ao centro e quatro em bairros periféricos.

Uma vez selecionadas as escolas participantes, o Departamento do Ensino Fundamental promoveu uma reunião com os respectivos diretores para apresentação do projeto, na qual se obteve a anuência de todos os diretores. Foram então sorteados, para cada turma de $1^{\circ}$ ano, treze alunos para serem convidados a participar da pesquisa, totalizando 351 crianças em 27 turmas. O convite foi realizado por meio de bilhete entregue aos pais, informando sobre um encontro na escola do seu filho para apresentação do projeto e em caso de aceite a assinatura do 
respectivo Termo de Consentimento Livre e Esclarecido (TCLE). Compareceram 244 pais, os quais foram informados sobre os objetivos, os procedimentos e a livre participação. Todos autorizaram a participação de seu filho.

Com as professoras do $1^{\circ}$ ano foram realizadas reuniões na própria escola, em horário de trabalho pedagógico, em que foram informadas sobre os objetivos, os procedimentos e a livre participação. Todas as 27 professoras concordaram em colaborar e foram orientadas sobre como preencher o SSRS-BR, o qual foi entregue devidamente preenchido no mês de dezembro, conforme solicitação da pesquisadora. O uso dos dados foi autorizado por pais e professores mediante a assinatura do TCLE.

Ao final da coleta apenas 25 professoras foram consideradas participantes, visto que uma professora precisou se afastar das atividades e não preencheu os instrumentos, e os alunos de outra não tiveram todas as avaliações realizadas e por isso a turma foi excluída das análises. Além disso, devido à ocorrência de muitas faltas de alunos à escola durante o mês de dezembro, período de finalização das atividades escolares, não foi possível a completa avaliação de todas as crianças. Portanto, apesar de todas as 244 crianças terem respondido a algum instrumento, apenas 186 participaram de todas as avaliações e compuseram a amostra final do projeto-mãe.

As avaliações com as crianças, que incluíram dados a serem analisados no presente estudo, aconteceram em duas etapas, no horário de aula. A primeira ocorreu nos meses de novembro e dezembro de 2010, quando as crianças cursavam o $1^{\circ}$ ano. As crianças responderam individualmente aos instrumentos IEE e ESI. A Provinha Brasil foi aplicada pela pesquisadoradoutoranda com a presença de uma auxiliar, que ajudou no monitoramento e no suporte aos participantes. Os grupos de avaliação foram compostos por 5 a 20 alunos, conforme espaço disponível para a atividade. A segunda etapa da avaliação das crianças ocorreu entre os meses de agosto e novembro de 2011, quando elas responderam individualmente aos instrumentos IEE e ESI.

\subsection{Procedimento de análise dos dados}

Primeiramente foram selecionados do banco de dados do projeto de doutorado de Correia-Zanini (2013), já disponível no programa SPSS versão 18, os participantes que tinham concluído dois anos de EI. Em seguida foram selecionadas as informações que eram de interesse para a composição do banco de dados desta pesquisa, que foram: pontuação no IDEB 2009 e localização das escolas, pontuação na Provinha Brasil e os resultados dos instrumentos ESI, 


\section{IEE e SSRS-BR.}

Em etapa preliminar de análise dos dados, foi verificada a normalidade da distribuição da amostra nas variáveis contínuas para sua utilização em análises paramétricas por meio do teste de Kolmogorov-Smirnov. Segundo o resultado desta estatística, somente a variável sintomas de estresse avaliada no $2^{\circ}$ ano do EF apresentou distribuição normal. Contudo, "Kline (1988 conforme citado por Marôco, 2011, p. 189) reporta dados de simulação que atestam que os modelos paramétricos são robustos para valores absolutos de assimetria ( $s k$ ) inferiores a $3 \mathrm{e}$ valores absolutos de achatamento $(k u)$ inferiores a 7-10". Ao verificar os valores de $s k$ e $k u$ das variáveis contínuas deste estudo observaram-se valores de assimetria abaixo de 1,02 e de curtose abaixo de 2,00, possibilitando o uso de testes paramétricos com estas variáveis.

A estatística descritiva foi aplicada para o levantamento de média e desvio-padrão das variáveis do estudo, bem como para mensurar o percentual de alunos que apresentavam sintomas de estresse. Para tornar comparáveis os valores obtidos nas variáveis da criança avaliadas com escalas diferentes, foi calculada a média relativa de cada variável. Esse cálculo consiste em dividir a média pelo número máximo de pontos que se pode obter na escala, resultando em um valor que pode variar de zero a um. Para avaliar a associação da variável presença de sintomas de estresse no $2^{\circ}$ ano à localização das escolas, foi utilizado o teste do Qui-Quadrado, uma estatística não-paramétrica para análise de varáveis categóricas.

O teste $t$ para amostras em pares foi utilizado para comparar o nível de estresse infantil e a percepção de estressores escolares no $1^{\circ}$ e no $2^{\circ}$ ano do EF. Foi utilizado o teste $t$ para amostras independentes para comparar crianças avaliadas com estresse e sem estresse quanto a variáveis da criança avaliadas no mesmo ano e comparar médias de indicadores de estresse de crianças avaliadas no $2^{\circ}$ ano de acordo com a localização e a pontuação no IDEB de suas escolas.

Para investigar possíveis associações entre a presença de estresse e percepção de estressores escolares em crianças no $2^{\circ}$ ano do EF e as variáveis da criança e das escolas (IDEB e localização) avaliadas no $1^{\circ}$ ano foram realizadas análises de correlação de Pearson, uma estatística que indica a magnitude da associação entre duas variáveis, podendo seus valores variar de -1 (correlação negativa perfeita) a 1 (correlação positiva perfeita). Para avaliar a força dessas associações adotamos os parâmetros de Hair, Black, Babin, Anderson e Tatham (2009), que considera as correlações como fracas quando atingem valores menores que 0,30 , moderadas entre 0,30 e 0,69, e fortes acima de 0,69. Esta mesma estatística foi utilizada para analisar associações entre os indicadores de estresse avaliados no $1^{\circ}$ e no $2^{\circ}$ ano. 
Análises de regressão linear múltipla pelo método Enter foram realizadas para estimar o valor preditivo das variáveis da criança e da escola avaliadas no $1^{\circ}$ ano sobre as variáveis preditas - sintomas de estresse e percepção de estressores escolares no $2^{\circ}$ ano. A escolha do método de análise de regressão respeitou os critérios apontados pela regra do polegar de Hill e Hill (2005) que estabelece condições que consideram o número de participantes da amostra e o número mínimo de variáveis independentes inseridas no modelo. Segundo esta regra, para a realização de análises de regressão pelo método Enter a dimensão mínima da amostra deve ser de 30 casos. Modelos com mais de seis variáveis independentes inseridas exigem uma amostra de tamanho mínimo igual a $5 \mathrm{k}$ (sendo $k$ o número de variáveis independentes). Para aumentar significativamente a probabilidade de generalizar com confiança os resultados é desejável aumentar a amostra para $\mathrm{n}=15 \mathrm{k}$.

Além disso, para a realização das análises de regressão linear múltipla foram seguidos os pressupostos balizados por Marôco (2011). Dentre eles, recomenda-se o uso de variáveis métricas. Para uso de variável não métrica ou categórica é aconselhável substituí-la por variáveis dummy, codificando-a como 0 (ausência de um atributo) ou 1 (presença de um atributo). Para esta pesquisa foram transformadas em dummy as variáveis pontuação da escola no IDEB ( 0 = média abaixo de 6,0 e 1 = média igual ou acima de 6,0) e localização da escola $(0=$ não estar na periferia e $1=$ estar na periferia $)$.

Outro pressuposto seguido conforme Marôco determina que as variáveis preditoras não devem apresentar multicolinearidade entre elas, isto é, devem ser independentes. A ausência de multicolinearidade foi estabelecida para valores de VIF (Variance Inflation Factor) não superiores a 5 e valores de Tolerância próximos a 1. Por fim, estipula que a covariância entre as variáveis aleatórias residuais seja nula, o que pode ser comprovado através do teste DurbinWatson, o qual deve ter valores próximos a 2.

Atendidas as restrições, foram explorados três modelos de regressão para a predição dos indicadores de estresse do $2^{\circ}$ ano. No primeiro deles foram inseridas no modelo de predição todas as variáveis da criança significativas na análise de correlação de Pearson com a variável predita mais as duas variáveis da escola. Assim, os preditores inseridos nas três análises de regressão para os diferentes indicadores de estresse diferiram, pois as variáveis da criança que foram significativas na análise de correlação de Pearson com a variável predita foram diferentes. Já o segundo modelo se diferenciou do primeiro apenas por excluir participante (s) com "outliers". Por fim, um terceiro modelo foi testado realizando as análises de regressão em duas etapas: primeiramente realizou-se análise de regressão inserindo todas as variáveis da 
criança que foram significativas na análise de correlação de Pearson com a variável predita e, posteriormente, realizou-se uma segunda análise de regressão inserindo no modelo os preditores significativos na análise de predição anterior mais as duas variáveis da escola. Essa exploração foi feita com a finalidade de selecionar, entre os modelos de predição possíveis dentro das restrições impostas pelos dados, aquele que apresentasse maiores índices de $\mathrm{R}^{2}$ ajustado, indicador este que fornece a porcentagem da variância que o modelo é capaz de explicar. 


\section{RESULTADOS}

Os resultados obtidos são apresentados na seguinte sequência: (3.1.) percentual de alunos com sintomas de estresse no $1^{\circ}$ e no $2^{\circ}$ ano do EF; (3.2) estatísticas descritivas das variáveis da criança no $1^{\circ}$ ano e comparação de crianças com e sem sintomas significativos de estresse quanto a essas variáveis; (3.3.) associações entre indicadores de estresse - sintomas de estresse e percepção de estressores escolares nos dois fatores (relacionado ao papel de estudante e às relações interpessoais) - avaliados em crianças no $2^{\circ}$ ano do EF e as variáveis de competência e ajustamento da criança avaliadas no $1^{\circ}$ ano; (3.4.) comparação e associação dos níveis de estresse e de percepção de estressores escolares nos dois fatores (relacionado ao papel de estudante e às relações interpessoais) dos alunos no $1^{\circ}$ e no $2^{\circ}$ ano do EF; (3.5.) caracterização das escolas e associações entre indicadores de estresse da criança avaliados no $2^{\circ}$ ano e as características da escola (pontuação no IDEB e localização); (3.6.) predição de manifestações de estresse (sintomas de estresse e percepção de estressores escolares relacionado ao papel de estudante e às relações interpessoais) avaliados no $2^{\circ}$ ano a partir de variáveis da criança e da escola avaliadas no $1^{\circ}$ ano.

\subsection{Percentual de alunos com sintomas de estresse}

No $1^{\circ}$ ano, $57 \%$ das crianças reportaram sintomas de estresse em algum nível, percentual que se elevou para $72 \%$ no $2^{\circ}$ ano. A associação da variável sexo à presença de estresse foi investigada através do teste do Qui-Quadrado, o qual não apresentou diferenças significativas entre meninas e meninos em relação à presença de estresse $\left(\chi^{2}(1)=0,422, p>0,05\right)$.

\subsection{Estatísticas descritivas das variáveis da criança e comparação de crianças com e sem estresse no $1^{\circ}$ ano do EF}

A Tabela 1 apresenta as médias, os desvios-padrão e as médias relativas (média/valor máximo) referentes às variáveis de competência e ajustamento da criança avaliadas no $1^{\circ}$ ano. Como se observa, as maiores médias relativas foram nas subescalas de habilidades sociais: responsabilidade e cooperação, competência acadêmica, asserção positiva e autocontrole. Os problemas de comportamento, por sua vez, obtiveram as menores médias relativas. As variáveis que apresentaram menor desvio-padrão foram as habilidades sociais de autodefesa 
e cooperação com os pares, enquanto a variável que apresentou maior desvio-padrão foi competência acadêmica.

Tabela 1 - Estatísticas descritivas das variáveis de competência e ajustamento da criança avaliadas no $1^{\circ}$ ano

\begin{tabular}{lccc}
\hline \multicolumn{1}{c}{ Variáveis } & Média & Desvio Padrão & Média Relativa \\
\hline Desempenho Acadêmico & 13,54 & 4,775 & 0,56 \\
Competência Acadêmica & 20,29 & 7,698 & 0,68 \\
Asserção Positiva & 8,78 & 2,879 & 0,63 \\
Autocontrole & 10,10 & 3,435 & 0,63 \\
Autodefesa & 3,18 & 1,510 & 0,53 \\
Responsabilidade e Cooperação & 10,04 & 3,472 & 0,72 \\
Cooperação com pares & 3,55 & 1,658 & 0,59 \\
PC - Externalizante & 5,01 & 3,757 & 0,36 \\
PC - Internalizante & 2,89 & 2,281 & 0,29 \\
\hline Not: No 157 & & &
\end{tabular}

Na Tabela 2 se encontram os resultados da comparação entre crianças avaliadas com estresse e sem sintomas significativos de estresse no $1^{\circ}$ ano, em relação às outras variáveis da criança avaliadas no mesmo ano. A partir desses dados, observa-se que as variáveis da criança, com exceção da asserção positiva, apresentam diferenças estatisticamente significativas entre os grupos com e sem estresse. As crianças do grupo sem estresse apresentam maiores médias nas variáveis desempenho acadêmico, competência acadêmica, autocontrole, autodefesa, responsabilidade e cooperação e cooperação com pares. Já as crianças do grupo com estresse apresentam maiores médias de problemas de comportamento externalizantes e internalizantes e maior percepção de estressores escolares nos dois fatores: tensões relacionadas ao papel do estudante e nas relações interpessoais. 
Tabela 2 - Comparação entre crianças avaliadas com estresse e sem estresse no $1^{\circ}$ ano nas outras variáveis da criança avaliadas no mesmo ano

\begin{tabular}{|c|c|c|c|}
\hline Variáveis & $\begin{array}{c}\text { Com } \\
\text { estresse } \\
\mathrm{n}=90 \\
\text { Média } \\
\text { (dp) }\end{array}$ & $\begin{array}{c}\text { Sem } \\
\text { estresse } \\
\mathrm{n}=67 \\
\text { Média } \\
\text { (dp) }\end{array}$ & $t$ \\
\hline Desempenho Acadêmico & $\begin{array}{l}12,13 \\
(4,22)\end{array}$ & $\begin{array}{l}15,42 \\
(4,86)\end{array}$ & $-4,521^{*}$ \\
\hline Competência Acadêmica & $\begin{array}{l}18,33 \\
(7,32)\end{array}$ & $\begin{array}{l}22,93 \\
(7,45)\end{array}$ & $-3,858 * *$ \\
\hline Asserção Positiva & $\begin{array}{c}8,27 \\
(2,86)\end{array}$ & $\begin{array}{c}9,48 \\
(2,78)\end{array}$ & $-2,657$ \\
\hline Autocontrole & $\begin{array}{c}9,12 \\
(3,71)\end{array}$ & $\begin{array}{l}11,42 \\
(2,51)\end{array}$ & $-4,624 * *$ \\
\hline Autodefesa & $\begin{array}{c}2,98 \\
(1,51)\end{array}$ & $\begin{array}{c}3,46 \\
(1,47)\end{array}$ & $-2,010^{*}$ \\
\hline Responsabilidade e Cooperação & $\begin{array}{c}8,98 \\
(3,61)\end{array}$ & $\begin{array}{l}11,48 \\
(2,7)\end{array}$ & $-4,965^{* *}$ \\
\hline Cooperação com pares & $\begin{array}{c}3,29 \\
(1,67)\end{array}$ & $\begin{array}{l}3,91 \\
(1,6)\end{array}$ & $-2,357^{*}$ \\
\hline PC - Externalizante & $\begin{array}{c}6,14 \\
(3,97)\end{array}$ & $\begin{array}{c}3,49 \\
(2,84)\end{array}$ & $4,883^{* *}$ \\
\hline PC - Internalizante & $\begin{array}{c}3,2 \\
(2,33)\end{array}$ & $\begin{array}{c}2,46 \\
(2,16)\end{array}$ & $2,023^{*}$ \\
\hline $\begin{array}{l}\text { Percepção de estressores escolares - F1: Tensões } \\
\text { relacionadas ao papel de estudante }\end{array}$ & $\begin{array}{l}15,04 \\
(7,91)\end{array}$ & $\begin{array}{l}9,46 \\
(6,61)\end{array}$ & $4,809 * *$ \\
\hline $\begin{array}{l}\text { Percepção de estressores escolares - F2: Tensões } \\
\text { cotidianas nas relações interpessoais }\end{array}$ & $\begin{array}{l}10,82 \\
(7,00)\end{array}$ & $\begin{array}{c}6,61 \\
(6,13)\end{array}$ & $3,930 * *$ \\
\hline
\end{tabular}

Nota: $* p<0,05 \quad * * p<0,001$

\subsection{Associações entre indicadores de estresse avaliados no $2^{\circ}$ ano do EF e as variáveis de competência e ajustamento da criança avaliadas no $1^{\circ}$ ano}

Na Tabela 3 estão apresentadas as correlações entre as variáveis da criança avaliadas no $1^{\circ}$ ano e as variáveis de desfecho relacionadas ao estresse no $2^{\circ}$ ano. Nota-se que todas as variáveis do $1^{\circ}$ ano correlacionaram significativamente com sintomas de estresse no $2^{\circ}$ ano, embora sejam em sua maioria correlações fracas. Apenas o desempenho acadêmico e a habilidade de responsabilidade e cooperação apresentaram correlações moderadas, ambas negativas, com sintomas de estresse do $2^{\circ}$ ano. 
Tabela 3 - Correlações entre as variáveis de competência e ajustamento da criança avaliadas no $1^{\circ}$ ano e as variáveis relacionadas ao estresse no $2^{\circ}$ ano

\begin{tabular}{|c|c|c|c|}
\hline \multirow[b]{2}{*}{ Variáveis avaliadas no $1^{\circ}$ ano } & \multirow[b]{2}{*}{$\begin{array}{l}\text { Sintomas de } \\
\text { Estresse }\end{array}$} & \multicolumn{2}{|c|}{ Percepção de estressores escolares } \\
\hline & & $\begin{array}{c}\mathrm{F} 1-\text { Tensões } \\
\text { relacionadas ao papel } \\
\text { de estudante }\end{array}$ & $\begin{array}{c}\mathrm{F} 2 \text { - Tensões } \\
\text { cotidianas nas } \\
\text { relações } \\
\text { interpessoais }\end{array}$ \\
\hline Desempenho Acadêmico & $-0,324 * *$ & $-0,341 * *$ & $-0,042$ \\
\hline Competência Acadêmica & $-0,196^{*}$ & $-0,352 * *$ & $-0,009$ \\
\hline Asserção positiva & $-0,171^{*}$ & $-0,192 *$ & 0,050 \\
\hline Autocontrole & $-0,266 * *$ & $-0,199 *$ & $-0,103$ \\
\hline Autodefesa & $-0,205 * *$ & $-0,133$ & 0,057 \\
\hline Responsabilidade e Cooperação & $-0,340 * *$ & $-0,369 * *$ & $-0,076$ \\
\hline Cooperação com pares & $-0,158^{*}$ & $-0,161 *$ & 0,004 \\
\hline PC - Externalizante & $0,295 * *$ & $0,245 * *$ & 0,099 \\
\hline PC - Internalizante & $0,161^{*}$ & $0,160 *$ & 0,093 \\
\hline
\end{tabular}

Nota: $\mathrm{N}=157 . * p<0,05 * * p<0,01$

Em relação à percepção de estressores escolares no fator tensões relacionadas ao papel do estudante, apenas a variável autodefesa não correlacionou significativamente. Dentre as variáveis que apresentaram correlação estatisticamente significativa, o desempenho acadêmico, a competência acadêmica e a habilidade de responsabilidade e cooperação apresentaram correlações moderadas, negativas, enquanto as demais apresentaram correlações fracas.

E, por último, no que se refere à percepção de estressores escolares no fator relações interpessoais no $2^{\circ}$ ano, não houve correlação estatisticamente significativa com nenhuma variável de ajustamento e competência do $1^{\circ}$ ano. 


\subsection{Comparação e associação dos níveis de estresse e de percepção de estressores escolares} nos dois fatores (relacionado ao papel de estudante e às relações interpessoais) dos alunos no $1^{\circ}$ e no $2^{\circ}$ ano do EF.

Estão na Tabela 4 os resultados das comparações entre as médias de sintomas de estresse e de percepção de estressores escolares obtidas pelos alunos no $1^{\circ}$ e no $2^{\circ}$ ano do EF. Como se observa, apenas os sintomas de estresse apresentam diferença estatisticamente significativa entre as médias obtidas na ocasião do $1^{\circ}$ e do $2^{\circ}$ ano. Nota-se que os alunos no $2^{\circ}$ ano apresentam maior média em comparação ao $1^{\circ}$ ano. A estatística não acusou diferença significativa entre os anos para percepção de estressores escolares.

Tabela 4 - Comparação das médias de sintomas de estresse e de percepção de estressores escolares obtidas pelos alunos no $1^{\circ}$ e no $2^{\circ}$ ano do $\mathrm{EF}$

\begin{tabular}{lcccc}
\hline \multicolumn{1}{c}{ Variáveis } & Ano & Média & $\begin{array}{c}\text { Desvio } \\
\text { Padrão }\end{array}$ & $t$ \\
\hline Sintomas de estresse & $1^{\text {o }}$ & 47,67 & 23,11 & $-3,091^{*}$ \\
& $2^{\text {o }}$ & 53,45 & 21,55 & \\
$\begin{array}{l}\text { Percepção de estressores escolares - F1: } \\
\text { Tensões relacionadas ao papel de estudante }\end{array}$ & $1^{\text {o }}$ & 12,66 & 7,865 & \multirow{2}{*}{$2^{\text {o }}$} \\
Percepção de estressores escolares - F2: & $1^{\text {o }}$ & 9,030 \\
Tensões cotidianas nas relações interpessoais & $2^{\text {o }}$ & 9,65 & 7,545 & \\
\hline
\end{tabular}

Nota: $\mathrm{N}=157 \quad * p<0,05$

Na Tabela 5 são apresentadas as correlações entre sintomas de estresse e percepção de estressores escolares nos dois fatores avaliados no $1^{\circ}$ e no $2^{\circ}$ ano. Nota-se que estas variáveis estão correlacionadas entre si. 
Tabela 5 - Correlações entre sintomas de estresse e percepção de estressores escolares avaliados no $1^{\circ}$ e no $2^{\circ}$ ano

\begin{tabular}{|c|c|c|c|c|c|c|}
\hline Variáveis & 1 & 2 & 3 & 4 & 5 & 6 \\
\hline 1 - Sintomas de estresse $-1^{\circ}$ ano & - & & & & & \\
\hline $\begin{array}{l}2 \text {-Percepção de estressores escolares - F1: } \\
\text { Tensões relacionadas ao papel de } \\
\text { estudante- } 1^{\circ} \text { ano }\end{array}$ & $0,400 * *$ & - & & & & \\
\hline $\begin{array}{l}3 \text { - Percepção de estressores escolares - } \\
\text { F2: Tensões cotidianas nas relações } \\
\text { interpessoais }-1^{\circ} \text { ano }\end{array}$ & $0,300 * *$ & $0,261 * *$ & - & & & \\
\hline 4 - Sintomas de estresse $-2^{\circ}$ ano & $0,451 * *$ & $0,309 * *$ & $0,339 * *$ & - & & \\
\hline $\begin{array}{l}5 \text { - Percepção de estressores escolares - } \\
\text { F1: Tensões relacionadas ao papel de } \\
\text { estudante- } 2^{\circ} \text { ano }\end{array}$ & $0,199 *$ & $0,448 * *$ & $0,172^{*}$ & $0,363 * *$ & - & \\
\hline $\begin{array}{l}6 \text { - Percepção de estressores escolares - } \\
\text { F2: Tensões cotidianas nas relações } \\
\text { interpessoais- } 2^{\circ} \text { ano }\end{array}$ & $0,164 *$ & 0,106 & $0,427 * *$ & $0,323 * *$ & $0,285 * *$ & - \\
\hline
\end{tabular}

Não houve correlação estatisticamente significativa apenas entre percepção de tensões relacionadas ao papel de estudante no $1^{\circ}$ ano e percepção de tensões nas relações interpessoais avaliada no $2^{\circ}$ ano. Especificamente no que se refere às correlações entre medidas da mesma variável obtidas em momentos diferentes, observam-se correlações moderadas, entre 0,43 (percepção de tensões cotidianas nas relações interpessoais) e 0,45 (sintomas de estresse).

\subsection{Caracterização das escolas e associações entre indicadores de estresse da criança avaliados no $2^{\circ}$ ano e as características da escola (pontuação no IDEB e localização).}

No Quadro 1 estão caracterizadas as escolas participantes de acordo com o IDEB 2009, tipos de ensino oferecidos e localização. 


\begin{tabular}{|c|c|c|c|c|c|}
\hline \multirow[b]{2}{*}{ Escola } & \multirow[b]{2}{*}{$\begin{array}{l}\mathrm{N}^{\circ} \text { de } \\
\text { partici- } \\
\text { pantes }\end{array}$} & \multicolumn{2}{|c|}{ IDEB } & \multirow[b]{2}{*}{ Tipos de Ensino } & \multirow[b]{2}{*}{ Localização } \\
\hline & & $\begin{array}{l}\text { Meta a ser } \\
\text { atingida em } \\
2009\end{array}$ & $\begin{array}{c}\text { Índice } \\
\text { obtido em } \\
2009\end{array}$ & & \\
\hline A & 31 & 6,3 & 6,5 & $1^{\circ}$ ao $5^{\circ}$ ano do $\mathrm{EF}$ & Centro \\
\hline B & 28 & 5,2 & 5,7 & $\begin{array}{c}\text { EI } \\
1^{\circ} \text { ao } 5^{\circ} \text { ano do EF } \\
\text { EJA }\end{array}$ & Periferia \\
\hline $\mathrm{C}$ & 31 & $-*$ & 5,2 & $\begin{array}{c}1^{\circ} \text { ao } 5^{\circ} \text { ano do } \mathrm{EF} \\
\text { EJA }\end{array}$ & Periferia \\
\hline $\mathrm{D}$ & 11 & 5,1 & 5,3 & $\begin{array}{c}1^{\circ} \text { ao } 9^{\circ} \text { ano do EF } \\
\text { EJA }\end{array}$ & $\begin{array}{l}\text { Entre Centro } \\
\text { e Periferia }\end{array}$ \\
\hline $\mathrm{E}$ & 13 & 5,0 & 5,1 & $1^{\circ}$ ao $5^{\circ}$ ano do EF & Periferia \\
\hline $\mathrm{F}$ & 12 & 6,2 & 6,5 & $1^{\circ}$ ao $9^{\circ}$ ano do $\mathrm{EF}$ & $\begin{array}{c}\text { Entre Centro } \\
\text { e Periferia }\end{array}$ \\
\hline G & 31 & 4,7 & 5,3 & $1^{\circ}$ ao $5^{\circ}$ ano do $\mathrm{EF}$ & Periferia \\
\hline
\end{tabular}

Nota. EJA: Educação de Jovens e Adultos

* Meta não estipulada para INEP por se tratar da primeira avaliação realizada pela escola.

Quadro 1. Caracterização das escolas participantes

Observa-se no Quadro 1 que todas as escolas atingiram a meta do IDEB para o ano de 2009, com exceção de uma escola para a qual não havia meta estabelecida por se tratar da primeira avaliação realizada pela instituição. Das sete escolas participantes, duas já atingiram pontuação do IDEB acima de 6. No que se refere à localização, uma escola está situada na região central, duas entre centro e periferia e quatro na periferia.

$\mathrm{Na}$ Tabela 6 estão especificadas as correlações entre as características das escolas (localização e IDEB 2009) e os sintomas de estresse e a percepção de estressores escolares nos dois fatores, avaliados no $2^{\mathbf{o}}$ ano. 
Tabela 6 - Correlações entre as características das escolas (localização e IDEB 2009) e os sintomas de estresse e a percepção de estressores escolares nos dois fatores avaliados no $2^{\circ}$ ano

\begin{tabular}{lcc}
\hline \multicolumn{1}{c}{ Variáveis } & Localização & IDEB - 2009 \\
\hline 1 - Sintomas de estresse & $0,256^{*}$ & $-0,255^{*}$ \\
$\begin{array}{l}\text { - Percepção de estressores escolares - F1: Tensões } \\
\text { relacionadas ao papel de estudante }\end{array}$ & 0,125 & $-0,079$ \\
$\begin{array}{l}3 \text { - Percepção de estressores escolares - F2: Tensões } \\
\text { cotidianas nas relações interpessoais }\end{array}$ & 0,134 & $-0,130$ \\
\hline
\end{tabular}
Nota: $\mathrm{N}=157 . \quad * p<0,01$

Como se observa na Tabela 6, as características das escolas se correlacionam apenas com os sintomas de estresse e essas correlações são fracas. A correlação entre localização e IDEB das escolas também foi investigada, apresentando uma correlação estatisticamente significativa, negativa e alta $(r=-0,84 ; p<0,01)$.

Na Tabela 7 são apresentadas as estatísticas descritivas e os resultados das comparações entre médias de sintomas de estresse e percepção de estressores escolares de crianças de acordo com a localização das suas escolas, no $2^{\mathrm{a}}$ ano.

Tabela 7 - Comparação das médias de sintomas de estresse e percepção de estressores escolares de crianças de acordo com a localização das suas escolas, no $2^{\mathrm{a}}$ ano

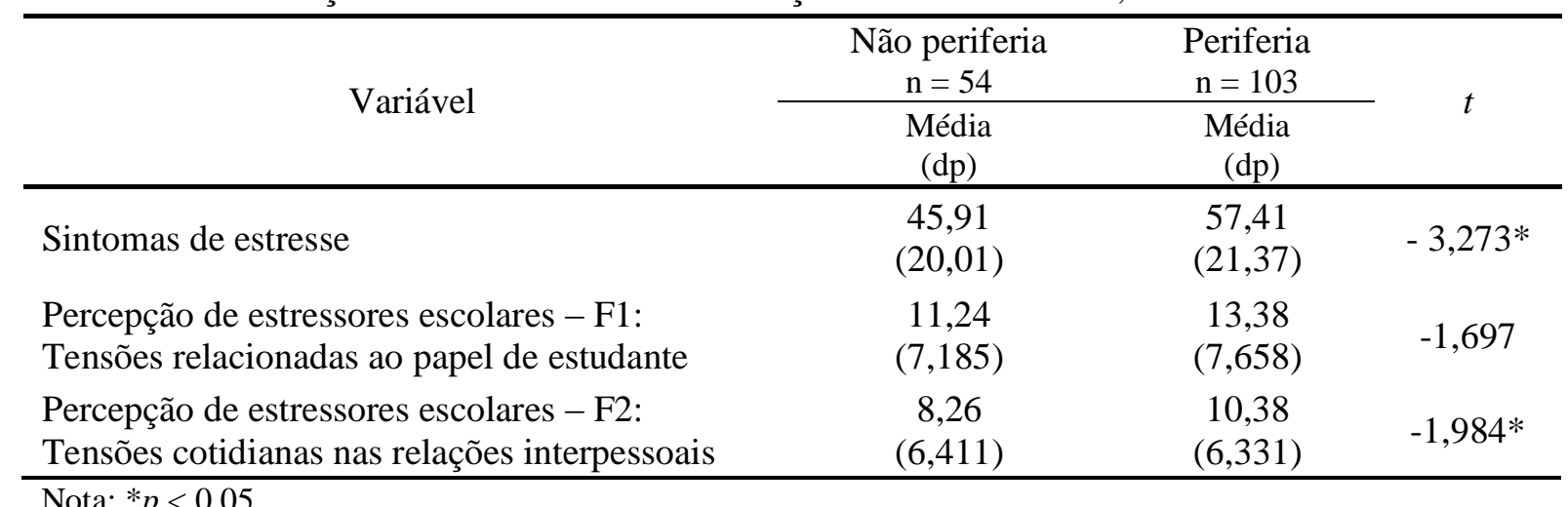

Como se observa na Tabela 7, houve diferenças estatisticamente significativas entre as médias de sintomas de estresse e de percepção de estressores escolares no fator 2 - Relações Interpessoais, de acordo com a localização, com maiores médias para a periferia.

Na Tabela 8, é apresentada a distribuição do número de crianças sem estresse e com estresse no $2^{\circ}$ ano de acordo com a localização das escolas. 
Tabela 8 - Distribuição do número de crianças sem estresse e com estresse no $2^{\circ}$ ano de acordo com a localização das escolas

\begin{tabular}{|c|c|c|c|}
\hline Localização & $\begin{array}{c}\text { Sem estresse } \\
n=44\end{array}$ & $\begin{array}{c}\text { Com estresse } \\
n=113\end{array}$ & $\chi^{2}(\mathrm{gl})$ \\
\hline $\begin{array}{l}\text { Não Periferia } \\
\mathrm{n}=54\end{array}$ & 22 & 32 & \\
\hline $\begin{array}{l}\text { Periferia } \\
\mathrm{n}=103\end{array}$ & 22 & 81 & $6,597(1)^{*}$ \\
\hline
\end{tabular}

Na Tabela 8 observa-se que a distribuição das crianças com e sem estresse não é aleatória em relação à localização da escola $(p<0,05)$. O exame dos números apresentados na Tabela 8 indica maior concentração de crianças com estresse nas escolas localizadas na periferia.

Na Tabela 9 estão expostos os resultados da comparação entre escolas que obtiveram média abaixo de 6 no IDEB $2009^{2}$ e escolas que alcançaram média igual ou acima de 6 , com referência aos sintomas de estresse e à percepção de estressores escolares das crianças avaliadas no $2^{\circ}$ ano.

Tabela 9 - Comparação entre escolas que obtiveram média abaixo de 6 no IDEB 2009 e escolas que obtiveram média igual ou acima de 6 segundo os sintomas de estresse e a percepção de estressores escolares das crianças no $2^{\circ}$ ano

\begin{tabular}{|c|c|c|c|}
\hline \multirow{2}{*}{ Variável } & $\begin{array}{c}\text { Média }<6,0 \\
n=114\end{array}$ & $\begin{array}{c}\text { Média } \geq 6,0 \\
n=43\end{array}$ & \multirow{2}{*}{$t$} \\
\hline & $\begin{array}{c}\text { Média } \\
\text { (dp) }\end{array}$ & $\begin{array}{l}\text { Média } \\
\text { (dp) }\end{array}$ & \\
\hline Sintomas de estresse & $\begin{array}{c}56,95 \\
(21,13)\end{array}$ & $\begin{array}{c}44,19 \\
(20,08)\end{array}$ & $3,420 * *$ \\
\hline $\begin{array}{l}\text { Percepção de estressores escolares - } \\
\text { F1: Tensões relacionadas ao papel de } \\
\text { estudante }\end{array}$ & $\begin{array}{l}11,98 \\
(7,46)\end{array}$ & $\begin{array}{l}12,89 \\
(7,59)\end{array}$ & $-0,684$ \\
\hline $\begin{array}{l}\text { Percepção de estressores escolares - } \\
\text { F2: Tensões cotidianas nas relações } \\
\text { interpessoais }\end{array}$ & $\begin{array}{c}44,19 \\
(20,08)\end{array}$ & $\begin{array}{l}10,11 \\
(6,33)\end{array}$ & 1,423 \\
\hline
\end{tabular}

Nota: $* * p<0,001$

\footnotetext{
${ }^{2}$ Recapitulando o exposto no Método, esse ponto de corte está baseado na meta do INEP, de média igual ou superior a 6 no IDEB em todas as escolas brasileiras até 2022, o que indicaria um sistema educacional comparável aos de países desenvolvidos (INEP, 2014).
} 
Na Tabela 9, é possível observar que houve diferença estatisticamente significativa apenas na variável sintomas de estresse, indicando que as crianças situadas em escolas que obtiveram média abaixo de 6 no IDEB apresentam maiores médias de sintomas de estresse.

\subsection{Predição de manifestações de estresse (sintomas de estresse e percepção de estressores escolares relacionado ao papel de estudante e às relações interpessoais) avaliados no $2^{\circ}$ ano a partir de variáveis da criança e da escola avaliadas no $1^{\circ}$ ano.}

Dentre os três modelos de predição explorados, o que mostrou maior poder de predição foi o primeiro, aquele em que, para cada indicador de estresse, foram inseridas no modelo todas as variáveis da criança significativamente correlacionadas com esse indicador, juntamente com as duas variáveis da escola. Portanto, os resultados apresentados nesta seção foram gerados por esse modelo.

A Tabela 10 apresenta os resultados da análise de predição de sintomas de estresse no $2^{\circ}$ ano incluindo no modelo todas as variáveis do $1^{\circ}$ ano que apresentaram correlação estatisticamente significativa com a variável sintomas de estresse no $2^{\circ}$ ano (observadas na Tabela 3) mais as variáveis da escola - localização e IDEB 2009 - ambas convertidas em variável dummy. A variável asserção positiva foi excluída do modelo final porque apresentou multicolinearidade (VIF maior que 5). 
Tabela 10 - Análise de regressão linear múltipla para a predição de sintomas de estresse no $2^{\circ}$ ano

\begin{tabular}{lccccc}
\hline \multicolumn{1}{c}{ Preditores do $1^{\text {o }}$ ano } & B & SE B & $\beta$ & $t$ & $p$ \\
\hline Desempenho Acadêmico & 0,154 & 0,462 & 0,034 & 0,333 & 0,739 \\
Competência Acadêmica & 0,364 & 0,268 & 0,130 & 1,360 & 0,176 \\
Autocontrole & 0,570 & 0,771 & 0,091 & 0,740 & 0,461 \\
Autodefesa & $-1,909$ & 1,364 & $-0,134$ & $-1,400$ & 0,164 \\
Responsabilidade e Cooperação & $-2,110$ & 0,918 & $-0,340$ & $-2,298 *$ & 0,023 \\
Cooperação com os pares & 1,129 & 1,373 & 0,087 & 0,822 & 0,412 \\
PC- Externalizante & 0,192 & 0,653 & 0,033 & 0,294 & 0,769 \\
$\begin{array}{l}\text { PC- Internalizante } \\
\text { Sintomas de estresse }\end{array}$ & 0,794 & 0,748 & 0,084 & 1,062 & 0,290 \\
$\begin{array}{l}\text { Percepção de estressores escolares - F1: } \\
\text { Tensões relacionadas ao papel de estudante }\end{array}$ & 0,259 & 0,076 & 0,278 & $3,410 *$ & 0,001 \\
$\begin{array}{l}\text { Percepção de estressores escolares - F2: } \\
\text { Tensões cotidianas nas relações interpessoais }\end{array}$ & 0,634 & 0,237 & 0,204 & $2,674 *$ & 0,008 \\
$\begin{array}{l}\text { Local - escola } \\
\text { IDEB - 2009 }\end{array}$ & 0,705 & 1,987 & 0,047 & 0,355 & 0,723 \\
\hline & $-9,122$ & 6,531 & $-0,189$ & $-1,397$ & 0,165 \\
\hline
\end{tabular}

Como se observa na Tabela 10, o modelo preditivo final explicou $29 \%$ da variância de sintomas de estresse no $2^{\circ}$ ano e contou com três variáveis do $1^{\circ}$ ano: sintomas de estresse, percepção de estressores escolares no fator 2- tensões cotidianas nas relações interpessoais, ambas de valor positivo, e a habilidade social de responsabilidade e cooperação, de valor negativo. Observa-se que a variável responsabilidade e cooperação foi a que apresentou maior coeficiente de regressão padronizado $(\beta=-0,340)$, mostrando ser o preditor mais forte, seguida das variáveis sintomas de estresse $(\beta=0,278)$ e percepção de estressores escolares no fator 2 tensões cotidianas nas relações interpessoais $(\beta=0,204)$. A ANOVA foi significativa $(\mathrm{F}(13,143)=6,007 ; p<0,001)$. O valor de Durbin-Watson foi de 2,103, próximo a 2,00, o que 
nos permite considerar que a covariância entre os resíduos é nula, e os valores de VIF e Tolerância das variáveis foram satisfatórios para as variáveis que fizeram parte do modelo final.

$\mathrm{Na}$ Tabela 11 se encontram os resultados da análise de predição de percepção de estressores escolares - F1: Tensões relacionadas ao papel de estudante no $2^{\circ}$ ano, inseridas no modelo todas as variáveis do $1^{\circ}$ ano que apresentaram correlação estatisticamente significativa com a variável predita (identificadas na Tabela 3) mais as variáveis da escola - localização e IDEB 2009 - ambas convertidas em variável dummy.

Tabela 11 - Análise de regressão linear múltipla para a predição de percepção de estressores escolares - F1: Tensões relacionadas ao papel de estudante, no $2^{\circ}$ ano

\begin{tabular}{|c|c|c|c|c|c|}
\hline Preditores do $1^{\circ}$ ano & $\mathrm{B}$ & SE B & $\mathrm{B}$ & $\mathrm{T}$ & $p$ \\
\hline Desempenho Acadêmico & $-0,009$ & 0,159 & $-0,005$ & $-0,053$ & 0,958 \\
\hline Competência Acadêmica & $-0,183$ & 0,097 & $-0,186$ & $-1,884$ & 0,062 \\
\hline Asserção positiva & $-0,058$ & 0,383 & $-0,022$ & $-0,153$ & 0,879 \\
\hline Autocontrole & 0,115 & 0,282 & 0,052 & 0,405 & 0,686 \\
\hline Responsabilidade e Cooperação & $-0,497$ & 0,333 & $-0,229$ & $-1,491$ & 0,138 \\
\hline Cooperação com os pares & 0,744 & 0,667 & 0,163 & 1,114 & 0,267 \\
\hline PC- Externalizante & 0,129 & 0,235 & 0,064 & 0,549 & 0,584 \\
\hline $\mathrm{PC}$-Internalizante & 0,343 & 0,277 & 0,104 & 1,239 & 0,218 \\
\hline Sintomas de estresse & $-0,038$ & 0,028 & $-0,118$ & $-1,383$ & 0,169 \\
\hline $\begin{array}{l}\text { Percepção de estressores escolares - F1: } \\
\text { Tensões relacionadas ao papel de estudante }\end{array}$ & 0,303 & 0,084 & 0,316 & $3,588^{* *}$ & 0,000 \\
\hline $\begin{array}{l}\text { Percepção de estressores escolares - F2: } \\
\text { Tensões cotidianas nas relações interpessoais }\end{array}$ & 0,090 & 0,086 & 0,083 & 1,052 & 0,294 \\
\hline Local - escola & 1,391 & 0,720 & 0,264 & 1,932 & 0,055 \\
\hline IDEB - 2009 & 4,160 & 2,365 & 0,247 & 1,759 & 0,081 \\
\hline
\end{tabular}

Como se pode observar na Tabela 11, a única variável deste modelo que prediz a variação nos valores da variável percepção de estressores escolares - F1: Tensões relacionadas 
ao papel de estudante, no $2^{\circ}$ ano, foi a mesma variável avaliada no ano anterior, com valor positivo, apresentando valor de coeficiente de regressão padronizado igual a 0,316. Este modelo foi significativo $(\mathrm{F}(13,143)=4,847 ; p<0,001)$ e explica $24 \%$ da variância. O valor de DurbinWatson foi de 2,081, assegurando ausência de auto-correlação entre resíduos, e os valores de VIF e Tolerância das variáveis foram satisfatórios. O modelo apresenta valores de $t$ próximos ao nível de significância adotado no estudo para as variáveis competência acadêmica, localização da escola e IDEB: respectivamente, 0,062, 0,055 e 0,081. Nota-se que tanto a localização na periferia como o IDEB $\geq 6$ teriam relação direta com tensões relacionadas ao papel de estudante, em presença das demais variáveis preditoras.

A Tabela 12 apresenta os resultados da análise de regressão linear múltipla para predição de percepção de estressores escolares F2: Tensões cotidianas nas relações interpessoais, no $2^{\circ}$ ano, com todas as variáveis do $1^{\circ}$ ano que apresentaram correlação significativa com esta variável (observados na Tabela 3) mais as variáveis da escola - local e IDEB 2009, ambas convertidas em variável dummy.

Tabela 12 - Análise de regressão linear múltipla para a predição de percepção de estressores escolares - F2: Tensões cotidianas nas relações interpessoais, no $2^{\circ}$ ano

\begin{tabular}{lccccc}
\hline \multicolumn{1}{c}{ Preditores do $1^{\circ}$ ano } & B & SE B & B & T & $P$ \\
\hline Sintomas de estresse & 0,010 & 0,021 & 0,036 & 0,472 & 0,638 \\
Percepção de estressores escolares - F2: & 0,374 & 0,073 & 0,404 & $5,130^{* *}$ & 0,000 \\
Tensões cotidianas nas relações interpessoais & 0,512 & 0,625 & 0,114 & 0,820 & 0,413 \\
Local - escola & 1,046 & 1,981 & 0,073 & 0,528 & 0,598 \\
IDEB - 2009 & & & &
\end{tabular}

Total $\mathrm{R}^{2}$ ajustado 0,167

A Tabela 12 mostra que o modelo de predição para a variável percepção de estressores escolares - F2: Tensões cotidianas nas relações interpessoais, no $2^{\circ}$ ano, foi significativo $(\mathrm{F}(4,152)=8,809 ; p<0,001)$ explicando $17 \%$ da variância. A única variável deste modelo que prediz a variação nos valores da variável critério foi a mesma variável avaliada no ano anterior, com coeficiente de regressão padronizado de valor 0,404. O valor de Durbin-Watson foi de 1,866, próximo a 2, e os valores de VIF e Tolerância das variáveis foram satisfatórios. 


\section{DISCUSSÃO}

O presente estudo teve como objetivo amplo investigar o estresse da transição entre a EI e o EF no contexto do EF de nove anos, uma vez que as pesquisas anteriores que estudaram o fenômeno da transição foram realizadas no contexto do EF de oito anos (Marturano et al., 2009; Marturano \& Gardinal, 2008; Trivellato-Ferreira \& Marturano, 2008). A investigação partiu da concepção do $1^{\circ}$ ano como um período de transição no ciclo da vida, no qual a criança se depara com diversas demandas do novo contexto. Segundo esta proposição, as tarefas adaptativas da transição são percebidas como fontes de tensões cotidianas presentes no contexto escolar quando excedem os recursos da criança (Marturano, 2008).

De forma mais específica, o estudo se propôs a agregar informações para o esclarecimento de pontos ainda obscuros, tais como a relação inversa entre competência e sintomas de estresse na transição do $1^{\circ}$ ano do EF, o curso desenvolvimental dos sintomas e das percepções de estresse nos anos inicias do EF, sua associação com as diferentes tarefas adaptativas e a influência da escola nos indicadores de estresse. Para isso, avaliaram-se indicadores de ajustamento e competências relacionadas ao desempenho acadêmico e social das crianças no $1^{\mathrm{o}}$ ano, estresse nos dois primeiros anos do EF e características da escola, especificamente sua localização e o IDEB. Por fim, esta investigação explorou modelos explicativos para os indicadores de estresse apresentados pelas crianças no $2^{\circ}$ ano do EF, a fim de lançar alguma luz sobre o preocupante achado dos altos índices de sintomas de estresse, identificados já no $1^{\circ}$ ano e exacerbados no $2^{\circ}$ ano (Correia-Zanini, 2013).

Nos resultados, $72 \%$ dos alunos do $2^{\circ}$ ano foram avaliados com estresse em algum nível. Este índice é preocupante por se tratar de uma amostra composta somente por crianças que frequentaram a EI, uma condição que atenua os efeitos do estresse associado à transição. Pesquisas anteriores apontam a passagem pela EI associada a maiores níveis de desempenho e ajustamento da criança nos resultados do primeiro ano do EF e uma maior aceitação pelos colegas, avaliações estas que correspondem a uma vivência subjetiva de menor estresse relacionado à escola (Marturano \& Gardinal, 2008; Pereira et al., 2011; Trivellato-Ferreira \& Marturano, 2008).

Não houve diferença significativa entre meninos e meninas em relação à presença de sintomas de estresse. Este resultado difere daqueles obtidos por Lipp, Arantes, Buriti e Witzig (2002) em amostra de escolares com idades entre 7 e 14 anos. Em contrapartida, vai ao encontro dos obtidos por outros autores que também utilizaram a ESI para avaliar sintomas de estresse 
em escolares, seja na $1^{\mathrm{a}}$ (Trivelatto-Ferreira \& Marturano, 2008) ou na $4^{\mathrm{a}}$ série do antigo EF de oito anos (Pacanaro \& Di Nucci, 2005).

As associações encontradas entre sintomas de estresse e os indicadores de percepção de tensões cotidianas presentes na escola sugerem que os sintomas de estresse apresentados pela criança apresentam relação com os problemas vivenciados no contexto escolar nos primeiros anos do EF. Estes achados corroboram que a escola é percebida pelas crianças como uma importante fonte de estresse no início do EF, principalmente no domínio do desempenho e das relações interpessoais (Marturano, 2008; Marturano et al., 2009; Marturano \& Gardinal, 2008; Rende \& Plomin, 1992; Stasiak, 2010).

Os resultados obtidos com a investigação de associações entre sintomas de estresse e variáveis de competência e ajustamento da criança no cumprimento das tarefas adaptativas na entrada para o EF confirmaram a previsão de uma relação inversa entre sintomas de estresse e competências, hipótese levantada com base nos achados do estudo de Trivellato-Ferreira e Marturano (2008) com alunos da antiga $1^{\text {a }}$ série. Ampliando os resultados correlacionais obtidos por aquelas autoras, que indicaram relação inversa entre sintomas de estresse por um lado e, por outro, desempenho acadêmico e ajustamento, os resultados da presente investigação apontaram que crianças sem sintomas de estresse, quando comparadas aos colegas com estresse, não apenas tiveram melhor desempenho acadêmico e menos problemas de comportamento, mas também apresentaram mais habilidades sociais, o que pode ser tomado como indício de maior competência social.

Desse modo, foi possível identificar associações entre sintomas de estresse e indicadores de cumprimento das principais tarefas de desenvolvimento do estágio escolar: ter sucesso no aprendizado acadêmico, formar laços de amizade com os coetâneos e aderir à normas da sociedade para conduta moral e comportamento prossocial (Masten \& Coatsworth, 1998). Para as três tarefas de desenvolvimento mencionadas, as associações se verificaram na direção esperada a partir da argumentação exposta na introdução, ou seja: relação inversa entre sintomas de estresse e os indicadores de realização acadêmica e interpessoal; relação direta entre sintomas de estresse e o indicador de dificuldade para adesão às normas, sinalizada pela presença de mais problemas de comportamento externalizante nas crianças com sintomas de estresse.

Além de mais problemas de comportamento externalizantes, crianças com sintomas de estresse apresentaram também mais problemas internalizantes e maiores níveis de percepção de estressores escolares relacionados ao papel do estudante e nas relações interpessoais. 
Associação entre sintomas de estresse e problemas de comportamento externalizantes foi relatada por Stasiak (2010) em crianças do $1^{\mathrm{a}}$ ano do $\mathrm{EF}$ de nove anos. Com respeito à relação entre percepção de estressores escolares e indicadores de ajustamento, Rende e Plomin (1992) já haviam encontrado associação positiva entre percepção de estressores escolares e problemas de comportamento externalizantes e internalizantes em crianças de 6-7 anos, alunas da $1^{\text {a }}$ série do ensino elementar em escolas norte-americanas.

No presente estudo, estendendo os resultados previamente obtidos no âmbito circunscrito do $1^{\circ}$ ano, tanto os indicadores de cumprimento das tarefas adaptativas na transição como a percepção de estressores escolares, avaliados no $1^{\circ}$ ano, foram associados à presença de sintomas de estresse no $2^{\circ}$ ano. Todas as medidas de habilidades sociais, desempenho, problemas de comportamento e percepção de estresse obtidas no $1^{\circ}$ ano mostraram correlações significativas com sintomas de estresse do $2^{\circ}$ ano. Maiores níveis de sintomas de estresse no $2^{\circ}$ ano estão associados a maiores níveis de problemas de comportamento e níveis mais baixos de desempenho acadêmico e habilidades sociais no ano anterior, assim como à percepção de maior exposição a estressores escolares. Estes resultados sugerem que crianças com menos recursos para lidar com as tarefas adaptativas do $1^{\circ}$ ano apresentaram maior dificuldade para se ajustarem às demandas deste período, perceberam-nas como fontes de tensões cotidianas na escola e desenvolveram sintomas de estresse. A associação dessas dificuldades do $1^{\circ}$ ano com a sintomatologia de estresse do $2^{\circ}$ ano alude à influência das experiências vividas na transição sobre os anos posteriores da vida escolar da criança (Entwisle \& Alexander, 1998; Marturano et al., 2009; Marturano \& Gardinal, 2008).

Associações também foram encontradas entre percepção de tensões relacionadas ao papel do estudante no $2^{\circ}$ ano e medidas de desempenho, habilidades sociais e problemas de comportamento no ano anterior. Portanto, níveis maiores de competência acadêmica e social e menores níveis de problemas de comportamento no $1^{\circ}$ ano estão associados com menor percepção de estresse nas tarefas relacionadas ao papel de estudante no $2^{\circ}$ ano. Esses achados se alinham aos obtidos anteriormente no âmbito da $1^{\text {a }}$ série do $\mathrm{EF}$, evidenciando melhor desempenho e ajustamento associados a menos estresse no domínio do desempenho (Marturano et al., 2009; Marturano \& Gardinal, 2008). Deste modo, crianças que se mostram mais competentes e ajustadas ao iniciarem o EF tendem a perceber menos tensões relacionadas ao papel de estudante, não apenas durante o ano inicial da transição, mas também no ano subsequente. 
Ainda sobre os resultados referentes à percepção de tensões relacionadas ao papel de estudante no $2^{\circ}$ ano, pode-se observar a concordância entre a percepção da criança dos desafios que encontra no domínio do seu papel de estudante e a avaliação realizada pelo seu professor sobre o seu desempenho nas tarefas adaptativas correspondentes. Essa concordância se dá também com a avaliação objetiva de desempenho.

Em contrapartida, não foi encontrada associação entre a percepção de tensões no domínio das relações interpessoais e a sua correspondente tarefa adaptativa, expressa, no presente estudo, por indicadores de habilidades sociais. Esse resultado concorda com os resultados obtidos por Marturano e Gardinal (2008) entre a EI e a $1^{\mathrm{a}}$ série do EF, e também por Gardinal-Pizato (2010) entre o $3^{\circ}$ e o $5^{\circ}$ ano.

Também não foram encontradas associações entre percepção de tensões nas relações interpessoais no $2^{\circ}$ ano e problemas de comportamento avaliados no $1^{\circ}$ ano. Estes resultados não se alinham com achados de pesquisas que investigaram associações entre problemas de comportamento e dificuldades no relacionamento interpessoal. Buhs et al. (2006) e Ladd e Troop-Gordon (2003) identificaram associação positiva entre problemas de comportamento avaliados pelos professores na pré-escola e exposição à rejeição e vitimização pelos pares, avaliada concomitantemente ou em anos subsequentes, indicando uma cronicidade dos problemas interpessoais. Esses achados permitiriam inferir uma associação positiva entre problemas de comportamento no início do EF e percepção de estressores escolares no domínio das relações interpessoais nos anos posteriores, o que não foi constatado na presente pesquisa, pelo menos no que diz respeito ao $2^{\circ}$ ano.

A discordância encontrada entre esses resultados pode ser entendida, em parte, como função de diferenças de método entre os estudos. Por exemplo, diferentes informantes e instrumentos de avaliação foram utilizados na investigação dos problemas presentes nas relações interpessoais do contexto escolar. $\mathrm{Na}$ presente pesquisa foi avaliada a própria percepção da criança sobre a ocorrência e o impacto destas situações. Já no estudo de Ladd e Troop-Gordon (2003) os problemas interpessoais foram avaliados pelos colegas; no de Buls et al. (2006) as avaliações foram obtidas a partir de três fontes: a aceitação foi avaliada pelos colegas de sala, a exclusão pelos professores e o abuso pela própria criança. Nestes dois estudos não se considerou a medida de impacto, apenas a ocorrência dessas situações.

Outro aspecto a considerar nessa análise é a composição do Fator 2 do IEE - Tensões cotidianas nas relações interpessoais. Esse fator, identificado com variações mínimas de composição em duas análises fatoriais exploratórias e uma confirmatória, realizadas seja com 
alunos do $1^{\circ}$ ou do $3^{\circ}$ ano do EF (Correia-Zanini, 2013; Gardinal-Pizato, 2010), inclui itens de relacionamento com os pares e também com o professor. Essa particularidade enfraquece o escore no Fator 2 como uma medida específica de estresse nas relações com os colegas, o que sem dúvida terá contribuído para as diferenças de resultados na comparação com estudos que focalizam especificamente as relações entre pares. No entanto, mesmo quando se segregam os itens de percepção de estresse no domínio do relacionamento com os colegas, como na pesquisa de Marturano e Gardinal (2008), não se observa associação entre problemas de comportamento e percepção de tensões cotidianas nos relacionamentos.

A partir do exposto, pode-se supor que crianças na fase de desenvolvimento investigada ainda são muito jovens para uma autopercepção apurada da sua participação na origem das tensões vivenciadas nos relacionamentos interpessoais, o que contribuiria para divergências entre suas avaliações e as das outras pessoas. Essa questão é passível de verificação empírica em novas pesquisas.

Contudo, foram encontradas associações entre os dois indicadores de percepção de estressores escolares avaliados no mesmo ano, sugerindo que crianças que apresentam dificuldades relacionadas ao papel de estudante também enfrentam problemas nas relações interpessoais. Estes achados vão ao encontro da literatura que aponta haver uma interdependência entre os domínios do desempenho escolar e dos relacionamentos interpessoais (Marturano \& Gardinal, 2008; Welsh, Parke, Widaman, \& O’Neil, 2001).

No que se refere ao domínio do relacionamento interpessoal, há consenso na literatura sobre o impacto negativo de problemas de interação da criança com o professor ou com os pares, separadamente ou em conjunto, sobre o desempenho escolar. Pesquisas realizadas no contexto da EI e do EF indicam que alunos cujas relações com os professores são conflituosas ou distantes estão mais sujeitos à rejeição por parte dos companheiros e a dificuldades acadêmicas persistentes (Hamre \& Pianta, 2001; Ladd et al., 1999; Silver et al., 2010).

A vitimização e a rejeição por pares têm sido associada concomitantemente e prospectivamente com menor engajamento na sala de aula e, por conseguinte, menores níveis de desempenho acadêmico (Buhs et al., 2006). Além disso, suas consequências para o ajustamento escolar podem ser amplificadas entre as crianças que têm um relacionamento conflituoso com o professor (Troop-Gordon \& Kuntz, 2013).

Partindo da concepção co-construtiva e transacional do conceito de competência (Marturano \& Ferreira, 2004; Masten \& Coatsworth, 1998), uma possível explicação para os processos implicados nessa associação entre os domínios acadêmico e interpessoal se alinham 
com as conclusões de Morales e Guerra (2006) a respeito do impacto das experiências sócioemocionais na escola sobre o desempenho acadêmico. Para estes autores, quando essas experiências são aversivas, a criança torna-se apreensiva sobre os possíveis acontecimentos da escola e passa a se esquivar deste contexto para evitar as situações que teme. Consequentemente, o seu interesse em aprender diminui, bem como o seu engajamento nas atividades pedagógicas, refletindo negativamente no seu desempenho acadêmico. Portanto, a deficiência no suporte social oferecido pela escola, principalmente pelo professor, prejudicam o desenvolvimento de competências social e acadêmica da criança.

Por outro lado, transações positivas com o ambiente escolar são promotoras de desenvolvimento de competências. O apoio dos colegas e dos professores e o sentimento de pertencer à escola propiciam o engajamento da criança na sala de aula. Quando isso ocorre no início do EF, repercute positivamente na motivação e no desempenho a longo prazo (Hughes \& Kwok, 2007). É mais provável que crianças engajadas, que participam ativamente das atividades em sala de aula, tenham experiências que alimentem o aprendizado e o desenvolvimento de habilidades. Deste modo, o engajamento na sala de aula exerce um papelchave, ligando a aceitação de pares ao desempenho nos anos posteriores (Bossaert, Doumen, Buyse, \& Verschueren, 2011).

No que se refere ao curso desenvolvimental dos sintomas de estresse e das percepções da criança sobre as tensões vivenciadas no âmbito escolar, os resultados indicaram correlações moderadas entre medidas de estresse tomadas nos dois momentos, sugerindo estabilidade dos indicadores de estresse. Estes resultados aludem a uma permanência no $2^{\circ}$ ano das dificuldades encontradas pela criança já no $1^{\circ}$ ano.

Em relação aos sintomas, a presença de estresse no $2^{\circ}$ ano foi maior do que no $1^{\circ}$ ano. Este resultado diverge dos achados de Lipp et al. (2002) que encontraram, em estudo transversal, maior porcentagem de alunos diagnosticados com estresse na $1^{\mathrm{a}}$ série, diminuindo progressivamente nos anos subsequentes até a $4^{\mathrm{a}}$ série. É importante ressaltar, porém, que os resultados dos dois estudos não são diretamente comparáveis, em pelo menos três quesitos: primeiro, a presente pesquisa trata da presença de sintomas, ao passo que Lipp et al. trabalharam com o diagnóstico clínico de estresse; segundo, este estudo acompanhou uma amostra de crianças em duas avaliações anuais consecutivas, ao passo que o estudo de Lipp et al. foi transversal; terceiro, aquela pesquisa foi conduzida no EF de 8 anos.

Diferente do que se observou em relação aos sintomas de estresse, a percepção de tensões na escola não variou significativamente entre o $1^{\circ}$ e o $2^{\circ}$ ano. No entanto, as medidas 
consecutivas de percepção de estresse estão as sociadas, indicando estabilidade. Estes resultados apontam que as crianças continuam percebendo as tarefas adaptativas como estressantes em intensidades similares ao passarem do $1^{\circ}$ para o $2^{\circ}$ ano.

Contrapondo-se a esses resultados, uma investigação realizada no contexto espanhol por Escobar et al. (2013) em uma amostra composta por crianças de 8 a 12 anos, que abarcou a avaliação de estressores cotidianos relacionados à saúde, família e escola, identificou que crianças mais jovens apresentam maiores níveis de estressores cotidianos. Essa discrepância encontrada entre os resultados da presente pesquisa e os do estudo de Escobar et al. deve ser analisada considerando primeiramente o emprego de instrumentos diferentes para avaliar os estressores cotidianos nestas investigações. No presente estudo a avaliação é composta por medida de frequência e impacto, enquanto no de Escobar et al. a criança indicava somente a ocorrência dos eventos, não considerando sua intensidade. Além disso, é possível supor que o curso desenvolvimental da percepção de estressores cotidianos presentes no contexto escolar se diferencie daqueles oriundos de outros contextos, como os relacionados à saúde e à família, uma vez que Escobar et al. não analisaram separadamente os diferentes contextos.

Em conjunto, o aumento dos sintomas de estresse e a não redução da percepção de estressores escolares entre o $1^{\mathrm{o}}$ e o $2^{\mathrm{o}}$ ano no contexto do EF de nove anos sugerem uma transição estendida, na qual a passagem para o $2^{\circ}$ ano não acarreta uma diminuição da suscetibilidade a estressores cotidianos, contrariamente ao que se poderia supor considerando a gradual familiarização das crianças ao novo contexto. Portanto, se as crianças continuam percebendo os estressores diários no $2^{\circ}$ ano com a mesma intensidade com que percebiam no $1^{\circ}$ ano, isso explica em parte o aumento dos sintomas de estresse, visto que a reação do organismo tende a se acentuar diante da exposição a estressores que persistem cronicamente.

Esses achados se alinham com os resultados discutidos anteriormente na presente seção. Nesse sentido, crianças com sintomas de estresse apresentam menor competência acadêmica e social, além de menor ajustamento, apresentando mais dificuldades de se adaptarem às novas demandas presentes no contexto escolar na entrada para o EF. E, ainda, estas dificuldades do $1^{\circ}$ ano estão associadas à presença de estresse no $2^{\circ}$ ano. Somada a esses resultados, a discussão com a literatura abordada nos parágrafos anteriores trouxe à tona a perpetuação de problemas nos domínios acadêmico e dos relacionamentos interpessoais ao longo da trajetória escolar, decorrentes de dificuldades na interação com colegas e professores a partir das primeiras interações na escola, contribuindo assim para a exposição crônica a estressores escolares. 
Além disso, o estresse por si só prejudica a concentração e o desenvolvimento do pensamento abstrato, compromete a habilidade de organização e contribui para a expressão de comportamentos agressivos, irritadiços, desobedientes e apáticos (Lipp, 2000). Estas consequências do estresse podem acarretar prejuízos para a criança na esfera do desempenho escolar e das relações interpessoais, obstando a diminuição da percepção de tensões no cotidiano escolar apesar da maior familiaridade ao contexto.

Considerando a importância das variáveis da escola no processo adaptativo da criança (Marturano \& Loureiro, 2003), o presente estudo também investigou, de forma exploratória, a existência de associações de características da escola, tais como pontuação no IDEB e localização, com os indicadores de estresse dos seus alunos. No que se refere ao IDEB, este não apresentou associações com os indicadores de percepção de estressores escolares, mas sim com sintomas de estresse. Nas correlações, a pontuação da escola no IDEB mostrou correlação negativa fraca com sintomas de estresse e, nas comparações de grupo, crianças provenientes de escolas com maiores médias no IDEB tiveram menores níveis de estresse. Estes resultados sugerem que a qualidade das escolas, aferida pelo desempenho médio do alunado, contribui para atenuar os sintomas de estresse dos seus alunos.

Pode-se alegar que é preciso cautela ao utilizar o IDEB como único indicador de qualidade do ensino das escolas. Primeiramente, os critérios utilizados para compor este indicador se restringem à combinação de informações do desempenho dos alunos no final das etapas de ensino com informações sobre o rendimento escolar. De acordo com estes critérios, escola boa é aquela em que o aluno apresenta bom desempenho em prova específica, frequenta às aulas e não repete de ano. Deste modo, o índice reflete o aprendizado do aluno como resultado e não o processo de ensino, desprezando outros aspectos que impactam sobre a qualidade das escolas, tais como a infraestrutura das mesmas e a valorização dos seus professores.

Outras limitações do IDEB são apresentadas por Soares e Xavier (2013). Segundo estes autores, por ter se tornado a única medida de qualidade da escola e dos sistemas de ensino, é comum escolas buscarem a maximização da sua pontuação. Segundo os autores, para este fim, as escolas podem utilizar maneiras pouco adequadas pedagogicamente valendo-se das lacunas que o IDEB possui. Uma das limitações sérias do IDEB é que só os alunos presentes ao teste são considerados, sendo exigidos pelo INEP a presença de apenas $50 \%$ dos alunos para divulgar os resultados da escola. Deste modo, se as ausências correspondem aos alunos mais fracos, as escolas com muitas ausências na prova podem ter seus valores no IDEB superestimados. 
Somado a isso, o IDEB também pode refletir variáveis contextuais, tais como o nível socioeconômico dos seus alunos. Soares e Xavier apontam uma forte correlação entre IDEB e nível socioeconômico dos seus alunos. Esta associação pode ser compreendida a partir da associação entre nível socioeconômico e desempenho da criança (Morales \& Guerra, 2006), uma medida componente do IDEB.

Apesar de todas as limitações do IDEB, não há como negar que o domínio de conteúdos, avaliado pelo índice, é o objetivo da instrução formal; também não há como ignorar os resultados sugestivos de que as crianças estariam menos estressadas em escolas com melhor pontuação. Com esses resultados, o presente estudo abre um campo de investigação para futuras pesquisas, que possam contemplar maior número de escolas nos diferentes níveis do IDEB e cruzamento deste índice com outros indicadores de qualidade das escolas, tais como qualificação do corpo docente, organização e segurança.

Os resultados obtidos com a investigação das associações entre localização da escola e indicadores de estresse também aludem à associação do estresse a variáveis contextuais. A localização da escola correlacionou com sintomas de estresse, apresentando uma associação de magnitude fraca. Além disso, as crianças das escolas periféricas apresentam maiores níveis de sintomas de estresse e percebem mais tensões nas relações interpessoais quando comparadas àquelas que estudam em regiões não periféricas, porém não se diferenciam no que se refere às tensões relacionadas ao papel de estudante. E, ainda, há uma maior concentração de crianças com sintomas de estresse na periferia. Portanto, em conjunto, estes resultados sugerem que as crianças das escolas de regiões periféricas apresentam maiores níveis de estresse e percebem mais tensões nas relações interpessoais presentes na escola.

Estes achados vão ao encontro da literatura que indica que alunos de escolas de regiões de baixo nível socioeconômico apresentam maiores níveis de estressores cotidianos (AmoneP'Olak et al., 2009; Escobar et al., 2013; Evans \& English, 2002). As interpretações dadas aos resultados pelos diversos autores podem ser assim resumidas: crianças provenientes destas áreas enfrentam com maior frequência uma gama de problemas, que inclui exposição à violência presente na vizinhança, moradia inadequada e desemprego dos pais, entre outros.

Segundo Morales e Guerra (2006), comunidades que apresentam altas taxas de pobreza se tornam uma fonte de estresse adicional para as famílias, o que, por sua vez, pode comprometer o desenvolvimento da criança. Estes autores explicam que diante das adversidades do contexto e da carência de recursos disponíveis, as famílias que vivem nestas condições precisam buscar novas oportunidades em busca de sobrevivência ou melhores 
condições de vida, expondo toda a família a uma série de mudanças. Concluem que este panorama aumenta as possibilidades de transições e rupturas familiares que levam a um ambiente carente de estrutura e estabilidade, uma provável fonte de estresse para pais e crianças que repercute negativamente no desenvolvimento delas.

A partir do exposto é possível inferir os processos implicados no desenvolvimento do estresse por crianças oriundas de escolas periféricas, justificando os maiores níveis de sintomas de estresse e maior percepção de estressores escolares no domínio das relações interpessoais apresentados por elas. As diversas dificuldades encontradas por crianças provenientes de regiões de baixo nível socioeconômico propiciariam a maior exposição a estressores cotidianos provenientes de diferentes contextos, tornando a criança mais vulnerável aos efeitos adversos do estresse.

Como exposto anteriormente, as consequências do estresse contribuem para a expressão de comportamentos desobedientes, agressivos, irritadiços e apáticos que prejudicam as relações interpessoais da criança (Lipp, 2000). Por haver uma maior concentração de crianças com sintomas de estresse na periferia, é possível que as interações deste contexto se tornem ainda mais difíceis, o que pode explicar, em parte, uma maior percepção de tensões neste domínio por crianças provenientes de escolas periféricas.

A alta correlação entre localização e IDEB encontrada nos resultados provavelmente reflete a associação bastante conhecida entre nível socioeconômico das famílias e desempenho escolar do alunado (Aikens \& Barbarin, 2008). Com efeito, Correia-Zanini (2013), em seu estudo longitudinal com a amostra ampliada da qual foi extraída a amostra do presente estudo $(\mathrm{N}=186)$, constatou que a localização da escola na periferia estava associada a menor nível socioeconômico dos participantes.

O presente estudo buscou lançar alguma luz sobre os altos índices de estresse encontrados no $2^{\circ}$ ano, explorando modelos explicativos compostos por variáveis da criança e da escola avaliadas na ocasião do $1^{\circ}$ ano, testados em análise de predição de sintomas de estresse e percepção de estressores escolares no $2^{\circ}$ ano, associados ao papel de estudante e às relações interpessoais. Tendo sido testados três modelos, os resultados indicaram um poder de predição modesto para o modelo que explicou a maior parcela de variabilidade nos resultados.

No que se refere à predição de sintomas de estresse no $2^{\circ}$ ano, três variáveis do $1^{\circ}$ ano foram significativas: sintomas de estresse, percepção de tensões nas relações interpessoais e habilidade social de responsabilidade e cooperação. A presença no modelo explicativo da 
própria variável sintomas de estresse avaliada no ano anterior sugere uma vulnerabilidade prévia ao estresse.

A variável que se mostrou como preditor mais forte foi a habilidade social de responsabilidade e cooperação, sugerindo que crianças que possuem esta habilidade mais desenvolvida no $1^{\circ}$ ano estão menos vulneráveis a apresentar sintomas de estresse no $2^{\circ}$ ano. Segundo Bandeira et al. (2009), esta habilidade abarca uma série de comportamentos da criança que demonstram compromisso com as tarefas e com as pessoas e disponibilidade para colaborar com o bom andamento das atividades, tais como seguir instruções do professor, manter a carteira limpa e arrumada, oferecer-se para ajudar colegas nas tarefas de classe e mostrar interesse nas atividades. Uma vez que tais comportamentos favorecem o bom relacionamento com professores e pares, assim como o engajamento nas atividades pedagógicas, supõe-se que esta habilidade tenha impacto importante no desempenho e no ajustamento da criança nos primeiros anos do EF, diminuindo assim o risco de uma escalada de sintomas de estresse. Este resultado se harmoniza com a discussão prévia de que a qualidade das relações estabelecidas com professores e pares no início do EF impactam sobre as interações futuras e sobre o desempenho acadêmico (Hamre \& Pianta, 2001; Ladd et al., 1999; Silver et al., 2010).

A presença da variável percepção de tensões nas relações interpessoais no modelo final de predição ressalta o impacto da qualidade das interações sociais no início do EF sobre a sintomatologia de estresse no $2^{\circ}$ ano. Ainda, a ausência da variável percepção de tensões no desempenho do papel de estudante como variável preditora pode indicar que as relações interpessoais são mais estressantes para as crianças neste período, tendo efeito maior sobre a sintomatologia do estresse. Somado a isso, a variável desempenho acadêmico também não apareceu no modelo final, reforçando a premissa de que o domínio do papel de estudante seja menos exigente para a criança nos primeiros anos do EF. Estes indícios vão ao encontro dos resultados de investigações que utilizaram o instrumento IEE e identificaram a relação com os pares como o domínio mais estressante no primeiro ano do EF, como os estudos de CorreiaZanini (2013) e Stasiak (2010), realizados no contexto do EF de 9 anos, e a pesquisa de Marturano e Gardinal (2008), ocorrida na situação do EF de 8 anos.

Além disso, a ausência dos problemas de comportamento no modelo final de predição indica que o ajustamento da criança à tarefa de aderir às normas e regras do contexto escolar na entrada para o EF não foi significativo para predição de sintomas de estresse no $2^{\circ}$ ano. Portanto, o modelo explicativo evidencia a importância da competência social da criança no início do EF, mais do que a sua competência acadêmica e ajustamento, nos resultados do estresse, sinalizando 
que a tarefa de situar-se na rede social ampliada seja a mais desafiadora nos primeiros anos do EF. Isso posto, deve-se acrescentar que a classe de habilidade social relevante como fator de proteção contra o estresse nessa transição, ou seja, responsabilidade/cooperação, traduz uma competência estreitamente associada ao desempenho acadêmico nos anos iniciais do EF (Correia-Zanini, 2013).

Por fim, a presença no modelo final da variável percepção de tensões nas relações interpessoais juntamente com a habilidade social de responsabilidade e cooperação alude a uma coerência entre a avaliação realizada pela criança e pelo professor sobre as interações sociais vivenciadas por ela no âmbito escolar, principalmente da relação entre professor e aluno.

Em conjunto, estes resultados ressaltam o papel do professor no manejo das dificuldades interpessoais dos seus alunos para a promoção de competências social e acadêmica e, por conseguinte, diminuição dos sintomas de estresse. Nesse sentido, esses achados oferecem subsídios para intervenções de prevenção ao estresse com ênfase na promoção de habilidades sociais.

Nas análises de predição de percepção de estressores escolares no $2^{\circ}$ ano, tanto no fator referente às tensões relacionadas ao papel de estudante quanto no fator referente às relações interpessoais, apenas a própria variável avaliada no ano anterior foi significativa para predição. Uma inferência que pode ser tirada desses resultados é que a percepção de estressores escolares seria pouco ou nada dependente dos antecedentes do aluno, em termos do seu desempenho acadêmico, suas habilidades sociais ou seu ajustamento comportamental prévio. Com base nos resultados das correlações apresentadas na Tabela 3, essa relativa independência já podia ser antecipada para a percepção de tensões nas relações interpessoais, todas não significativas. No caso das tensões relacionadas ao papel de estudante, as correlações foram significativas, porém não permaneceram no modelo de regressão; apenas competência acadêmica apresentou, na regressão, probabilidade próxima de $5 \%(p=0,062)$ associada à estatística $t$.

Se a percepção de estressores escolares é relativamente independente das variáveis do aluno, outra inferência que pode ser feita é que ela seria então situacional, ou seja, dependente da experiência no contexto. Assim, somente a experiência prévia com determinados estressores, expressa na percepção de tensões cotidianas no $1^{\circ}$ ano, prediz a percepção de estressores da mesma natureza no ano subsequente.

No desdobramento dessas inferências, pode-se supor que o contato com situações estressantes no cotidiano escolar teria um efeito persistente, predispondo a criança a reafirmar suas percepções quando questionada no ano seguinte. Ou então, pode-se também supor que são 
as interações no ambiente escolar que de fato tendem a se repetir para cada criança, em ciclos retroalimentados. As duas interpretações não são mutuamente excludentes; elas de fato se complementam.

Assim, as crianças que percebem tensões no $1^{\circ}$ ano do EF no desempenho do seu papel de estudante continuam encontrando dificuldades neste domínio no $2^{\circ}$ ano, não superando-as mesmo com uma maior familiarização ao contexto escolar. Da mesma forma ocorre para a percepção de tensões nas relações interpessoais.

No que se refere às variáveis da escola (IDEB e localização), observa-se que elas não foram significativas em nenhum modelo explicativo para indicadores de estresse no $2^{\circ}$ ano. Entretanto, como discutido anteriormente nesta seção, as variáveis da escola utilizadas no presente estudo foram caracterizadas de forma grosseira e estão associadas a outras variáveis contextuais não identificadas. Portanto, não é pertinente afirmar a partir destes resultados que as escolas não desempenham qualquer impacto nos indicadores de estresse das crianças. Deste modo, outras variáveis da escola deveriam ser incluídas no modelo a fim de contemplar as atuações da escola que contribuem para o ajustamento e competência de seus alunos, bem como caracterizá-las de forma mais refinada, na tentativa de separá-las de variáveis intervenientes, como as do contexto mais amplo em que as escolas se situam. 


\section{CONCLUSÃO}

As escolhas metodológicas realizadas na presente pesquisa foram coerentes com o referencial teórico adotado e atingiram seu objetivo maior de contribuir com a investigação do estresse presente na transição da EI para o EF, no contexto do EF de nove anos. Em contrapartida, essas escolhas acarretaram algumas limitações para a compreensão e generalização dos resultados desta pesquisa, sugerindo novas perguntas para futuras investigações.

Uma dessas limitações refere-se à maneira de medir o estresse. No presente estudo foi utilizada a presença de sintomas de estresse, ao invés da identificação de fases ou diagnóstico clínico de estresse. A literatura apresenta uma diversidade de métodos empregados na avaliação do estresse infantil entre as pesquisas, o que limita algumas comparações entre os resultados desses estudos.

Outra limitação desta pesquisa refere-se à amostra das escolas, que contemplou apenas as municipais. Para maior generalização dos resultados, sugere-se para futuras pesquisas a inclusão de outros tipos de escolas, como as estaduais e as particulares.

No que se refere à qualidade das escolas, investigada neste estudo por meio do IDEB 2009, as pontuações das escolas participantes foram próximas e variaram entre 5,1 e 6,5, isto é, variaram em torno da meta estipulada pelo INEP para todas as escolas brasileiras até o ano de 2022 como indicativo de boa qualidade. Nesse sentido, as escolas que compuseram a amostra desta pesquisa se mostraram de boa qualidade quando comparada a outras escolas brasileiras. Portanto, para melhor investigação desta variável e aumento do poder de generalização dos resultados, sugere-se a participação de escolas com médias no IDEB em diferentes níveis. Além disso, como há indícios de que o IDEB está associado ao nível socioeconômico das famílias, sugere-se que pesquisas futuras utilizem outros métodos para avaliar a qualidade da escola, considerando, por exemplo, a sua infraestrutura, a qualificação do corpo docente, organização e segurança.

Sobre a variável localização da escola, o número de escolas e de alunos participantes provenientes de cada região da cidade foi bastante desigual. Apenas uma escola representou a região central enquanto quatro representaram a região periférica. Pesquisas com a participação de maior número de escolas em diferentes regiões do município poderão contornar essa limitação.

Apesar das limitações apresentadas nos parágrafos anteriores, a pesquisa trouxe 
resultados consistentes que contribuíram para a compreensão do estresse presente na transição para o EF, no contexto do EF de nove ano. A relevância desta investigação foi confirmada pela elevada taxa de sintomas de estresse encontrada na amostra deste estudo, o que sinaliza uma demanda por trabalhos de intervenção voltados à prevenção de problemas associados ao estresse em escolares.

A associação encontrada entre sintomas de estresse e indicadores de percepção de tensões cotidianas presentes no âmbito escolar reforçaram a suposição de que os problemas vivenciados na escola contribuem para a sintomatologia do estresse apresentada por escolares. Entretanto, conforme identificado na revisão de literatura, há uma escassez de pesquisas que investigam quais demandas presentes na escola são geradoras de estresse para criança nos anos iniciais do EF, o que enfatiza ainda mais a necessidade de estudos sobre o tema.

Nesse sentido, esta pesquisa buscou identificar condições presentes no contexto escolar associadas à presença de estresse de modo a oferecer subsídios para práticas de intervenção. Confirmou-se a relação inversa entre estresse e variáveis de competência e ajustamento, indicando que crianças menos competente academicamente e socialmente e com problemas de comportamento internalizantes e externalizantes apresentam maiores dificuldades para se adaptarem às tarefas de desenvolvimento apresentadas na entrada do EF.

Além disso, a investigação do curso desenvolvimental dos indicadores de estresse permitiu identificar uma transição estendida no início do EF, que extrapola o $1^{\circ}$ ano, apontando que as dificuldades de adaptação da criança aos desafios do ingresso no EF não têm sido superadas com a familiarização gradual ao contexto. Nesse sentido, podemos supor que as estratégias utilizadas pela escola para oferecer suporte, acolhimento e promoção de trocas interpessoais positivas aos seus alunos nesta fase não têm sido eficientes na superação dos desafios apresentados pelas tarefas adaptativas da transição, favorecendo a cronicidade dos problemas enfrentados pelas crianças na escola e consequentemente o aumento nos níveis de estresse no $2^{\circ}$ ano, conforme identificado no presente estudo.

Também foram investigadas, de forma exploratória, as associações de variáveis da escola (IDEB e localização) com os indicadores de estresse dos seus alunos. Quanto ao IDEB, como há indícios de que ele está associado ao nível socioeconômico das famílias, sugere-se que pesquisas futuras utilizem outros métodos para avaliar a qualidade da escola, considerando, por exemplo, a sua infraestrutura e o preparo e valorização dos seus professores.

No que se refere à localização das escolas, os resultados também remetem a uma associação do estresse a variáveis contextuais. Os níveis mais elevados de sintomas de estresse 
e a maior percepção de tensões nas relações interpessoais encontrados nas crianças de escolas situadas na periferia reforçam os achados da literatura que indicam que crianças que vivem em bairros periféricos enfrentam uma gama maior de problemas fora do contexto escolar, tornandoas mais vulneráveis ao efeitos adversos do estresse, o que, por sua vez, prejudica o seu desempenho acadêmico e social, colaborando para a cronicidade destes problemas.

Por fim, a exploração de modelos explicativos para os altos índices de estresse apresentados por crianças no $2^{\circ}$ ano do EF conseguiu atingir o seu objetivo de lançar alguma luz sobre os processos implicados nessas associações. Os resultados obtidos evidenciaram a habilidade social de responsabilidade e cooperação avaliada no $1^{\circ}$ ano como importante fator de proteção contra sintomas de estresse no $2^{\circ}$ ano, ao passo que a percepção da criança de tensões nas interações interpessoais no $1^{\circ}$ ano foi o principal fator de risco para futura sintomatologia de estresse. Os resultados reforçam outros achados encontrados na literatura que indicam o domínio das interações com os colegas e professores como o mais desafiador para a criança na entrada do EF e apontam que crianças mais competentes socialmente estão menos vulneráveis ao estresse.

Portanto, os resultados obtidos na presente pesquisa sinalizam a importância do papel do professor no processo adaptativo da criança nos primeiros anos do EF através do oferecimento de acolhimento, suporte e promoção de experiências sócio-emocionais positivas aos seus alunos, além do manejo habilidoso dos conflitos interpessoais presentes no contexto escolar. Nesse sentido, intervenções com ênfase na promoção de habilidades sociais das crianças podem ser profícuas na prevenção do estresse.

Entretanto, outros modelos devem ser explorados a fim de preencher as lacunas evidenciadas nesta pesquisa, como por exemplo a inserção de outras variáveis da escola e da criança e de variáveis da família e do contexto. Além disso, dada a relevância das relações interpessoais, sugere-se para futuras pesquisas acrescentar o emprego da avaliação da competência social da criança a partir da perspectiva de seus pares às avaliações de auto-relato e às do professor.

Finalmente, vale ressaltar alguns cuidados metodológicos na realização desta investigação que permitiram atingir os seus objetivos. O emprego do delineamento prospectivo e o número de participantes da amostra permitiram analisar com certa margem de confiabilidade o curso desenvolvimental dos indicadores de estresse, bem como permitiram a aplicação de análises de predição dos mesmos. As variáveis da criança escolhidas para esta investigação se mostraram coerentes no sentido de abordarem as competências exigidas pelas tarefas 
adaptativas na transição para o EF. Além disso, o uso de diferentes medidas e informantes (a própria criança e os professores) sobre estas competências fortaleceu o estudo, possibilitando a ampliação das análises. Ainda, destaca-se a avaliação da percepção da criança sobre os eventos comumente estressantes presentes no contexto escolar para além da identificação da mera ocorrência de tais eventos, por meio do instrumento IEE, o que torna a mensuração das tensões vivenciadas pela criança mais genuína. 


\section{REFERÊNCIAS $^{3}$}

Achenbach, T. M., \& Edelbrock, C. S. (1979). The child behavior profile: II. Boys aged 1216 and girls aged 6-11 and 12-16. Journal of Consulting and Clinical Psychology, 47(2), 223-233.

Aikens, N. L., \& Barbarin, O. (2008). Socioeconomic differences in reading trajectories: The contribution of family, neighborhood, and school contexts. Journal of Educational Psychology, 100(2), 235-251.

Amone-P’Olak, K., Ormel, J., Huisman, M., Verhulst, F. C., Oldehinkel, A. J., \& Burger, H. (2009). Life stressors as mediators of the relation between socioeconomic position and mental health problems in early adolescence. The TRAILS study. Journal of the American Academy of Child \& Adolescent Psychiatry, 48(10), 1031-1038.

Aspesi, C. C., Dessen, M. A., \& Chagas, J. F. (2005). A ciência do desenvolvimento humano: Uma perspectiva interdisciplinar. In M. A. Dessen \& A. C. Costa Jr. (Orgs.), A ciência do desenvolvimento humano: Tendências atuais e perspectivas futuras (pp. 19-36). Porto Alegre, RS: Artmed.

Bandeira, M., Del Prette, Z. A. P., Del Prette, A., \& Magalhães. T. (2009). Validação das escalas de habilidades sociais, comportamentos problemáticos e competência acadêmica (SSRR-BR) para o ensino fundamental. Psicologia: Teoria e Pesquisa, 25(2), 271-282.

Barrett, S., \& Heubeck, B. G. (2000). Relationships between school hassles and uplifts and anxiety and conduct problems in grades 3 and 4. Journal of Applied Developmental Psychology, 21(5), 537-554.

Bee, H. (1997). O ciclo vital. Porto Alegre, RS: Artmed.

Belsky, J. (2010). Desenvolvimento humano: Experienciando o ciclo da vida. Porto Alegre, RS: Artmed.

Bridley, A., \& Jordan, S. S. (2012). Child routines moderate daily hassles and Children's Psychological Adjustment. Children's Health Care, 41(2), 129-144.

Bossaert, G., Doumen, S., Buyse, E., \& Verschueren, K. (2011). Predicting children's academic achievement after the transition to first grade: A two-year longitudinal study. Journal of Applied Development Psychology, 32(2), 47-57.

Buhs, S., Ladd, G. W., \& Herald, S. H. (2006). Peer exclusion and victimization: Processes that mediate the relation between peer group rejection and children's classroom engagement and achievement? Journal of Educational Psychology, 98(1), 1-13.

\footnotetext{
${ }^{3}$ De acordo com o estilo APA - American Psychological Association
} 
Chen, X., Huang, X., Chang, L., Wang, L., \& Li, D. (2010). Aggression, social competence, and academic achievement in Chinese children: a 5-year longitudinal study. Development and Psychopathology, 22(3), 583-592.

Correia-Zanini, M. R. G. (2013). Um estudo prospectivo sobre o percurso escolar de crianças nos primeiros anos do ensino fundamental (Tese de doutorado). Recuperado de http://www.teses.usp.br/teses/disponiveis/59/59137/tde-06012014-100239/

Del Prette, Z. A. P., \& Prette, A. (2003). Habilidades sociais e dificuldades de aprendizagem: Teoria e pesquisa sob um enfoque multimodal. In Z. A. P. Del Prette \& A. Del Prette (Orgs.), Habilidades sociais, desenvolvimento e aprendizagem: Questões conceituais, avaliação e intervenção (pp. 167-206). Campinas, SP: Alínea.

Del Prette, Z. A. P., \& Del Prette, A. (2005). Psicologia das habilidades sociais na infância: Teoria e prática. Petrópolis, RJ: Vozes.

Elias, M. J. (1989). School stress and children: Estimating the costs. Journal of School Psychology, 27(4), 393-407.

Entwisle, D. R., \& Alexander, K. L. (1998). Facilitating the transition to first grade: The nature of transition and research on factors affecting it. The Elementary School Journal, 98(4), 351-365.

Eriksson, U., \& Sellström, E. (2010). School demands and subjective health complaints among Swedish schoolchildren: A multilevel study. Scandinavian Journal of Public Health, 38(4), 344-350.

Escobar, M., Alarcón, R., Blanca, M. J., Fernández-Baena, F. J., Rosel, J. F., \& Trianes, M. V. (2013). Daily stressors in school-age children: A multilevel approach. School Psychology Quartely, 28(3), 227-238.

Escobar, M., Trianes, M. V., Fernández-Baena, F. J., \& Páez, J. M. (2010). Relaciones entre aceptación sociométrica escolar e inadaptación socioemocional, estrés cotidiano y afrontamento. Revista Latinoamericana de Psicologia, 42(3), 469-479.

Evans, G. W., \& English, K. (2002). The environment of poverty: Multiple stressor exposure, psychophysiological stress, and socioemotional adjustment. Child Development, 73(4), 1238-1248.

Fletcher, A. C., Walls, J. K., Eanes, A. Y., \& Troutman, D. R. (2010). Maternal management of social relationships as a correlate of children's school-based experiences. The School Community Journal, 20(2), 159-181.

Gardinal-Pizato, E. C. (2010). Um estudo longitudinal de trajetórias de desempenho escolar (Tese de doutorado não publicada). Universidade de São Paulo, Ribeirão Preto, SP.

Gardinal-Pizato, E. C., Marturano, E. M., \& Fontaine, A. M. G. V. (2014). Trajetórias de habilidades sociais e problemas de comportamento no ensino fundamental: Influência da educação infantil. Psicologia: Reflexão e Crítica, 27(1), 189-197. 
Hair, J. F., Black, W. C., Babin, B. J., Anderson, R. E., \& Tatham, R.L. (2009). Análise multivariada de dados (A. S. Sant' Anna, Trad., 6a ed.). Porto Alegre, RS: Bookman.

Hamre, B. K., \& Pianta, R. C. (2001). Early teacher-child relationships and the trajectory of children's school outcomes through eighth grade. Child Development, 72(2), 625-638.

Hesketh, T., Zhen, Y., Lu, L., Dong, Z. X., Jun, Y. X., \& Xing, Z. W. (2010). Stress and psychosomatic symptoms in Chinese school children: Cross-sectional survey. Archives of Disease in Childhood, 95(2), 136-40.

Hjern, A., Alfven, G., \& Östberg, V. (2008). School stressors, psychological complaints and psychosomatic pain. Acta Paediatrica, 97(1), 112-117.

Hill, M. M., \& Hill, A. (2005). Investigação por questionário. Lisboa, Portugal: Edições Sílabo.

Hughes, J., \& Kwok, O. (2007). Influence of student-teacher and parent-teacher relationships on lower achieving readers' engagement and achievement in the primary grades. Journal of Educational Psychology, 99(1), 39-51.

Instituto Nacional de Estudos e Pesquisas Educacionais Anísio Teixeira. (2009). Provinha Brasil: Kit Teste 2009. Recuperado de http://provinhabrasil.inep.gov.br

Instituto Nacional de Estudos e Pesquisas Educacionais Anísio Teixeira. (2014). O que são as metas? Recuperado de http://portal.inep.gov.br/web/portal-ideb/o-que-sao-as-metas

Jacobson, G., Riesch, S. K., Temkin, B. M., Kedrowski, K. M., \& Kluba, N. (2011) Students feeling unsafe in school: Fifth graders' experiences. Journal of School Nursing, 27(2), 149-159.

Kanner, A. D., Coyne, J. C., Schaefer, C., \& Lazarus, R. S. (1981). Comparison of two modes of stress measurement: Daily hassles and uplifts versus major life events. Journal of Behavioral Medicine, 4(1), 1-39.

Kraag, G., Zeegers, M. P., Kok, G., Hosmane, C., \& Abu-Saad, H. H. (2006). School programs targeting stress management in children and adolescents: A meta-analysis. Journal of School Psychology, 44(6), 449-472.

Ladd, G. W., Birch, S. H., \& Buhs, E. S. (1999). Children's social and scholastic lives in kindergarten: Related spheres of influence? Child Development, 70(6), 1373-1400.

Ladd, G. W., \& Troop-Gordon, W. (2003). The role of chronic peer difficulties in the development of children's psychological adjustment problems. Child Development, 74(5), 1344-1367.

Lemes, S. O., Fisberg, M., Rocha, G. M., Ferrini, L. G., Martins, G., Silviero, K., \& Ataka, M. A. (2003). Stress infantil e desempenho escolar: Avaliação de crianças de $1^{\mathrm{a}}$ a $4^{\mathrm{a}}$ série de uma escola pública do município de São Paulo. Revista Estudos de Psicologia, 20(1), 5-14. 
Lipp, M. E. N. (2000). O stress da criança e suas consequências. In M. E. N. Lipp (Org.), Crianças estressadas: Causas, sintomas e soluções (pp. 13-42). Campinas, SP: Papirus.

Lipp, M. E. N., Arantes, J. P., Buriti, M. S., \& Witzig, T. (2002). O estresse em escolares. Psicologia Escolar e Educacional, 6(1), 51-56.

Lipp, M. E. N., \& Lucarelli, M. D. M. (2008). Escala de Estresse Infantil (ESI): Manual. São Paulo, SP: Casa do psicólogo.

Marôco, J. (2011). Análise estatística com o SPSS Statistics (5a ed.). Pero Pinheiro, Portugal: Report Number.

Marturano, E. M. (2008). Tensões cotidianas na transição da primeira série: Um enfoque de desenvolvimento. Psicologia em Estudo, 13(1), 77-85.

Marturano, E. M., \& Ferreira, M. C. T. (2004). A criança com queixas escolares e sua família. In E. M. Marturano, M. B. M. Linhares, \& S. R. Loureiro (Orgs.), Vulnerabilidade e proteção: Indicadores na trajetória de desenvolvimento do escolar (pp. 217-249). São Paulo, SP: Casa do Psicólogo.

Marturano, E. M., \& Gardinal, E. C. (2008). Um estudo prospectivo sobre o estresse cotidiano na $1^{\text {a }}$ série. Alethéia, (27), 81-97.

Marturano, E. M., \& Gardinal-Pizato, E. C. (2010). Qualidade da escola, desempenho e percepção de tensões cotidianas no início do ensino fundamental [Resumos, CD]. Reunião Anual da Sociedade Brasileira de Psicologia, 40. Curitiba, PR: SBP.

Marturano, E. M., \& Loureiro, S. R. (2003). O desenvolvimento socioemocional e as queixas escolares. In Z. A. P. Del Prette \& A. Del Prette (Orgs.), Habilidades sociais, desenvolvimento e aprendizagem: Questões conceituais, avaliação e intervenção (pp. 257-291). Campinas, SP: Alínea.

Marturano, E. M., Trivelatto-Ferreira, M. C., \& Gardinal, E. C. (2009). Estresse cotidiano na transição da $1^{\mathrm{a}}$ série: Percepção dos alunos e associação com desempenho e ajustamento. Psicologia Reflexão e Crítica, 22(1), 93-101.

Masten, A. S., \& Coatsworth, J. D. (1998). The development of competence in favorable and unfavorable environments: Lessons from research on successful children. American Psychologist, 53(2), 205-220.

Morales, J. R., \& Guerra, N. G. (2006). Effects of multiple context and cumulative stress on urban children's adjustment in elementary school. Child Development, 77(4), 907-923.

Pacanaro, S. V., \& Di Nucci, E. P. (2005). Stress infantil: Uma comparação entre meninos e meninas do ensino fundamental. Argumento, 7(13), 65-76.

Pereira, M. T., Marturano, E. M., Gardinal-Pizato, E. C., \& Fontaine, A. M. G. (2011). Possíveis contribuições da educação infantil no desempenho e competência social de escolares. Psicologia Escolar e Educacional, 15(1), 101-109. 
Rende, R. D., \& Plomin, R. (1992). Relations between first grade stress, temperament, and behavior problems. Journal of Applied Developmental Psychology, 13(4), 435-446.

Santa Lucia, R. C., Gesten, E., Rendina-Gobioff, G., Epstein, M., Kaufmann, D., Salcedo, O., \& Gadd, R. (2000). Children's school adjustment: A developmental transactional systems perspective. Journal of Applied Developmental Psychology, 21(4), 429-446.

Silver, R. B., Measelle, J. R., Armstrong, J. M., \& Essex, M. J. (2010). The impact of parents, child care providers, teachers, and peers on early externalizing trajectories. Journal of School Psychology, 48(6), 555-583.

Soares, J. F., \& Xavier, F. P. (2013). Pressupostos educacionais e estatísticos do IDEB. Educação \& Sociedade, 34(124), 903-923.

Stasiak, G. R. (2010). Transição ao primeiro ano do ensino fundamental: Percepção do estresse pelas crianças, suas características psicológicas e variáveis do seu contexto familiar (Dissertação de mestrado não publicada). Universidade Federal do Paraná, Curitiba, PR.

Trivellato-Ferreira, M. C., \& Marturano, E. M. M. (2008). Recursos da criança, da família e da escola predizem competência na transição da $1^{\text {a }}$ série. Revista Interamericana de Psicologia, 42(3), 407-410.

Troop-Gordon, W., \& Kuntz, J. K. (2013). The unique and interactive contributions of peer victimization and teacher-child relationships to children's school adjustment. Journal of Abnormal Child Psychology, 41(8), 1191-1202.

Vanaelst, B., De Vriendt, T., Huybrechts, I., Rinaldi, S., \& De Henauw, S. (2012). Epidemiological approaches to measure childhood stress. Paediatric and Perinatal Epidemiology, 26(3), 280-297.

Welsh, M., Parke, R. D., Widaman, K., \& O’Neil, R. (2001). Linkages between children's social and academic competence: A longitudinal analysis. Journal of School Psychology, $39(6), 463-481$. 


\section{ANEXO A \\ Universidade de São Paulo \\ Faculdade de Filosofia, Ciências e Letras de Ribeirão Preto \\ Comitê de Ética em Pesquisa}

Campus de Ribeirão Preto

Of.CEtP/FFCLRP-USP/068/-vjmc

Ribeirão Preto, 07 de agosto de 2014

Prezada Pesquisadora,

Comunicamos a V. Sa. que a emenda referente ao projeto de pesquisa intitulado "UM ESTUdo PROSPECTIVO SOBRE O PERCURSO ESCOLAR DE CRIANÇAS NOS DOIS PRIMEIROS ANOS DO ENSINO FUNDAMENTAL" solicitando a inclusão da pesquisadora Érica Taciana dos Santos Crepaldi que fará análise de parte dos dados colhidos no projeto, constituindo novo projeto intitulado "SINTOMAS DE ESTRESSE E PERCEPÇÃO DE ESTRESSORES ESCOLARES NO 2० ANO DO ENSINO SUPERIOR" foi analisada pelo Comitê de Ética em Pesquisa da FFCLRP-USP, em sua $134^{\mathrm{a}}$ Reunião Ordinária, realizada em 07.08.2014, e enquadrado na categoria: APROVADO (Processo CEP FFCLRP n 528/2010 - 2010.1.1794.59.2). A emenda foi enviada ao CEP em 25 de julho de 2013.

Solicitamos que eventuais modificações ou emendas ao projeto de pesquisa sejam apresentadas ao CEP, de forma sucinta, identificando a parte do projeto a ser modificada e suas justificativas, e que, ao término do estudo, um relatório final seja entregue, via Plataforma Brasil.

Atenciosamente,

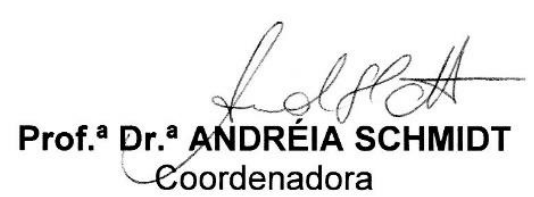

Coordenadora

À Senhora

Érica Taciana dos Santos Crepaldi

Programa de Pós-Graduação em Psicologia da FFCLRP - USP

CEP - Comitê de Ética em Pesquisa da FFCLRP USP

Fone: (16) 3602-4811

Fax: (16) 3633-2660 (direto) ou 3633-5015

Avenida Bandeirantes, 3900 - bloco 3 - sala 16 - 14040-901 - Ribeirão Preto - SP - Brasil

Homepage: http://www.ffclrp.usp.br - e-mail: coetp@ffclrp.usp.br 